\title{
Demographic Patterns of Reurbanisation and Housing in Metropolitan Regions in the US and Germany*
}

\author{
Karoline Brombach, Johann Jessen, Stefan Siedentop, \\ Philipp Zakrzewski
}

\begin{abstract}
After decades of decline, first signs of a central and inner city revitalisation were noticed towards the end of the 1980s in North American metropolitan areas. The repopulation and redevelopment of the metropolitan cores - often referred to as "reurbanisation", "urban renaissance" or "back-to-the-city-movement" - has accelerated since then and is today one of the outstanding characteristics of recent urban development in the US. In Western and Central European urban regions, reurbanisation patterns were detected some years later although starting from a different level, as the inner cities have never faced a process of decay to the extent that was known in North American cities. At present, reurbanisation is intensely debated in urban and regional research. Although the evidence of reurbanisation is hardly questioned any longer, there is considerable uncertainty about how this new pattern of population change can be explained, how long it will last and how it will change the spatial urban structure of metropolitan areas in the long run. In this paper, we comparatively investigate recent trends of urban development in the US and Germany based on both survey and case study methods, with a focus on demographic patterns and housing. Our results suggest that reurbanisation is a universal trend in large metro regions in the Global North, manifesting itself as a significant repopulation and densification of core areas. At the same time, we found considerable divergence in terms of scale, dynamics and sociodemographic composition of reurbanisation patterns in the selected regions of the US and Germany.
\end{abstract}

Keywords: Reurbanisation - Comparative urban research - US · Germany · Metropolitan areas $\cdot$ Demographic development $\cdot$ Housing

This article belongs to a special issue on reurbanisation. 


\section{Introduction}

The reurbanisation debate in Europe started in the early 1980s as something not too far away from an academic exercise. Van den Berg's et al. (1982) classic work "Urban Europe: A Study of Growth and Decline" introduced the cyclic urbanisation model with its fourth phase of "reurbanisation" following after urbanisation, suburbanisation and disurbanisation. But shortly thereafter evidence of an urban resurgence during the 1980s was provided by empirical studies for both Europe and North America (Cheshire 1995; Bourne 1992; Frey 1993; Nowlan/Stewart 1991; Siebel/Häußermann 1987). Whereas most North American cities kept on growing during the 1990s, the delicate signs of urban recovery in parts of Europe have been washed away by world history shortly after they occurred. In the aftermath of the fall of the iron curtain, the European migration and urban development patterns have substantially changed compared to the 1980s. Especially in Germany, the urban development debate of the 1990s turned to a renewed suburbanisation phase. Also the issue of heavily shrinking cities entered the discourse around the turn of the century (see for example Müller/Siedentop 2004). But already in the second half of the 1990s, the Urban Task Force around the British architect Richard Rogers started reasoning about the challenges of English cities and the means of an "urban renaissance" (Urban Task Force 1999). And then, like phoenix from the ashes, reurbanisation raised again to become one of the most controversial topics amongst urban researchers from the mid-2000s until recently. Even though the discussion gained momentum on both sides of the Atlantic (for the US see i.e. Sohmer/Lang 2001; Fishman 2005; Landis 2009; and for Europe i.e. Buzar et al. 2007; Turok/Mykhnenko 2008; Lambert/Boddy 2010; Brake/Herfert 2012; Rérat 2012), discourses seemed to take place separated from each other.

However, the fragmentation of the reurbanisation debate is not only caused by the separation between a North American and a European point of view, but also by diverging concepts that have been employed to analyse and explain the reurbanisation phenomenon (Glatter/Siedhoff 2008; Engler 2013). At least four approaches can be distinguished: (1) quantitative concepts of reurbanisation as a process of demographic change in metropolitan regions, (2) qualitative concepts of reurbanisation focussing on consumer-preferences of private households or (3) on emerging new urban economies as predominant driver, and finally, (4) normative concepts of policy-driven reurbanisation. In many contributions more than one of these approaches is presented as essentially interconnected.

(1) The quantitative dimension of reurbanisation can be addressed as a process of population concentration within the urban core of a metropolitan region (van den Berg et al. 1982). Alternatively, reurbanisation can be quantified as a central city's positive migration balance with its suburbs (Schmitz-Veltin 2014) or as the growth of cities or city centres after a period of population decline (Rérat 2012; Sohmer/Lang 2001; Birch 2005; Jessen et al. 2012; Turok/ Mykhnenko 2008). The impact of shifting demographic structures and migration patterns on urban population dynamics is highly complex and multifac- 
eted. Nonetheless two strong trends can be identified which lead towards a demography-driven reurbanisation. One trend is the international immigration towards large cities (Fishman 2005; Rérat 2012). Following this line of argumentation, major cities are particularly attractive for in-migrants because of the larger labour market for non- or little qualified workers and because of the larger rental housing markets. The other one is the positive internal migration balance of cities for the age group of young adults (Moos 2015; Growe/Münter 2010). This phenomenon is related to the concentration of education facilities and broader job opportunities in large cities.

(2) Reurbanisation is also discussed as a qualitative improvement of the urban environment that meets the consumer preferences of certain sought after population groups, such as the creative class (Florida 2002). This understanding is part of many urban regeneration policies. Via flagship projects, the upgrading of public infrastructure such as transit, or increased private sector investment in inner city housing, young, well-educated and affluent population groups are attracted to recapture the cities (Lever 1993; Helbrecht 1996; Van Criekingen 2009). Additionally, certain types of private households like singles, childless couples or single-parents that always have prioritised living in central locations are growing due to social change (Glasze/Graze 2007; Ogden/Hall 2004; Siebel 2008). Some urban researchers focus on the growing demand for urban amenities (Glaeser/Gottlieb 2006; Clark et al. 2002) that is closely related to the increase of private income. Highly qualified employees from service or knowledge industries apparently prefer inner city areas with easy access to a broad range of urban amenities. If so, the ever increasing number of high-educated persons will enlarge the population potential of city dwellers.

(3) Nevertheless, urban environments are not only appealing to private households but form also ideal settings for knowledge-based economic activities. In a knowledge economy, locational advantages and locally effective spillovers are expected to become more and more important (Brake 2012; Storper) Scott 2009). It is argued that a tight network and close collaboration between actors in the knowledge-based economy increase the competitiveness on a supra-regional level. According to this argument, major cities offer more opportunities for contact and exchange, they boast of more universities and research institutions, they are interconnected with global business networks and they offer a higher portion of highly qualified labour force (Geppert/ Gornig 2010). The creation of new jobs in the knowledge-based economy stimulates demographic growth; thus, economy- and demography-driven reurbanisation processes are closely interrelated. Yet, as it is fairly unlikely that every city can participate in a job growth driven by the knowledge economy, the reurbanisation model only applies to a limited number of places. 
(4) Finally, we find approaches that stress urban policies as a driving factor of reurbanisation processes. Thus, reurbanisation can be seen as a normative concern which unfolds as a set of hard or soft policies aiming at strengthening cities in general or certain fields of the urban realm, especially housing. The municipalities have reacted on trends of urban decline and stagnation by pursuing active policies to increase the cities' competitiveness. In doing so, they were in parts supported by national urban policy programmes. Vast investments into prestigious urban infrastructure like sports or cultural facilities are meant to be catalysts for brownfield regeneration. According to this understanding, reurbanisation is at least in parts a product of local and national urban policies. But as some studies from the US (Danie/sen/Lang 2010), England (Lambert/Boddy 2010) and Switzerland (Koll-Schretzenmayr/Kramp 2010) have shown, the population growth in inner city areas does not always correspond with increased housing production, although such a correspondence is highly plausible (Jessen/Mayer 2010). Probably, in some cases, recent market development has benefitted from, boosted and sometimes overtaken long-term planning and regeneration strategies.

The debate on reurbanisation has been confronted with some fundamental critique for largely neglecting its social consequences. In this perspective it is argued that the reurbanisation discourse suffers from a hidden normative bias by ignoring the results of the gentrification research (Holm 2012; Van Criekingen 2009). This shift is also reflected in recent urban practice as municipalities have conducted studies on processes of gentrification that they experienced.

At present, reurbanisation is still intensely debated in urban and regional research. There are multifaceted findings on the variations in urban systems and processes of change for selected cities. The evidence of reurbanisation - seen as the population growth in major cities following a longer period of population losses and paralleled by structural change - is hardly questioned any longer. However, there is considerable uncertainty about how these tendencies both in North-American and in European metropolitan regions can be explained, how long they will last and if all cities will be exposed to them in the long run.

This comparative urban study contributes to the overall debate on divergence or convergence of trends in urban development in the United States and Europe (Le Galès/Zagrodzki 2006). The overall research question is whether universal forces of economic and social change lead to new population growth in urban cores and how urban policies as well as market forces intervene in this process. Thus it is very much about similarities and differences and how they can be explained (Nivola 1999; Gordon/Cox 2012). We present some major findings of the REURBAN research project funded by the German Research Foundation that focused on processes of reurbanisation in major metropolitan regions in Germany and the US. It pursued two goals: First, we wanted to generate hypotheses that allow for a well-founded social and spatial differentiation of reurbanisation and its driving forces. Second, we conceptualised our analysis as a contribution to the debate on convergence/ divergence of European and North American urban development and urban policy. 
We consider German and American urban regions as suitable for such a comparison, since renewed population growth in urban centres is evident in both countries, but stark differences have been put forward in significant contextual conditions such as demographic development, housing preferences, path-dependent urban structures and the institutional framework of urban planning. We ask why a particular phenomenon such as reurbanisation has taken place even under strikingly different regional framework conditions. Comparative research thus allows the evaluation of concepts across national (or in this case even continental) boundaries. We believe that comparative research on a particular phenomenon like reurbanisation sharpens our view on generalisable and specific, context-related patterns and processes as well as their respective driving forces (Bourne 2008).

To date, there are relatively few empirical urban studies with an international comparative approach. One of the reasons lies in the tremendous methodological pitfalls of cross-cultural comparative urban research (Kantor/Savitch 2005). Pierre (2005) has rightly stressed the gap between the methodological challenges of comparative research and the evenly demanding conceptual requirements of urban research in general: "Urbanists tend to emphasise the importance of adopting a holistic and context embracing approach to understand the contemporary city or the historical trajectory of urban development. Embarking on a comparative research agenda entails by necessity some degree of reductionism as a step in preparing empirical observations for comparative assessment" (Pierre 2005: 447). This holds also true for the complex concept of reurbanisation, where highly ambitious conceptual frameworks have been developed (among others: Engler 2013); comparative studies on this subject are necessarily more "parsimonious" in character than "in-depth, context-embracing, idiographic studies that one sees much in urban politics" (Pierre 2005: 445).

In order to address methodological pitfalls we decided for a multi-level case study approach. The comparison takes place on two levels that are interconnected. On the regional level, eight metropolitan areas in Germany and the US were examined in terms of population change patterns over the 1990s and 2000s (see for the results Siedentop et al. 2018). The selection of case regions was based on a comparative statistical analysis of population change in the 50 largest US American and 14 largest German metropolitan regions (section 2). On the local level, smallscale spatial characteristics of reurbanisation and their driving forces were examined with two case studies: the metropolitan areas of Portland (Oregon) and Stuttgart (Baden-Württemberg), taken from the sample analysed on the regional level (as "embedded" case studies). Thus, we wanted to identify in more detail diverging and converging trends of reurbanisation in the US and Germany by investigating the modes of urban population growth on neighbourhood level and how they were materialised in the local built environment. Moreover, we tried to find out how this growth was stimulated, channeled, protected or restricted through local planning strategies (section 3). 


\section{Reurbanisation trends in Metropolitan Regions in Germany and the US}

\subsection{Selection of regions and data sources}

In this section we examine patterns of population change at metropolitan scales in four German and four American regions: Dresden, Frankfurt/Main, Munich and Stuttgart as well as Atlanta, GA, Boston, MA, Philadelphia, PA and Portland, OR. This sample is selected from a comparative statistical analysis on population change in the 50 largest US and 14 largest German metropolitan regions that we conducted for the time period of 1990 to 2010 based on US census data and on German municipal statistics. The choice of regions is based on the most-different systems design because a range of specific contextual conditions should be met: divergent patterns in urban form, demographic and economic dynamics or governance structures.

To neutralise the statistical effects of formally defined regional boundaries and subdivisions of the region we employed a ring zone model using rings with a defined radius from a given centre (the townhall). Ring zone models are an established method for analysing spatial structures and developments; they are especially appropriate for showing core-edge relationships and developmental gradients within urban areas (Estiri et al. 2015; Juday 2015). In this case, the outer ring zone (representing the outer boundary) has a radius of $50 \mathrm{~km}$ around a defined regional centre and the internal structure is defined by ring-zones with a width of $5 \mathrm{~km}$ in the inner regional areas and $10 \mathrm{~km}$ in the outer areas. Based on census tracts or municipal boundaries (0-5 km, 5-10 km, 10-20 km, 20-30 km, 30-40 km, 40-50 km) these six rings, were aggregated to three areas of analysis: The "core area" formed the innermost ring zone, with a maximum distance of $5 \mathrm{~km}$ from the regional centre. An "inner suburban zone" comprised of statistical spatial units at a distance between 5 and $20 \mathrm{~km}$, while the "outer suburban zone" represented spatial units at a distance of at least $20 \mathrm{~km}$. Thus, equivalent analytical regions were created with largely circular form and approximately the same dimensions.

For the study regions in the United States, data from the company GeoLytics were used covering the results from the census of 1990, 2000 and 2010. The data are available in a homogenised form for the territorial boundaries from the year 2000, which means that the census data from 1990 and 2010 are projected onto the territorial boundaries of 2000. The German data originate from the respective statistical offices of the federal states. To detect intra-city developments in German core cities we included data at the district level for the respective cities that the statistical offices also provided.

\subsection{Convergent and divergent patterns of population change}

A comparison of population change patterns in American and German metro regions during the 1990s and 2000s initially - unsurprisingly - reveals marked differences that express the divergent demographic growth pressure in both countries. 
Disparities particularly arise in regard to the intensity of population growth, but also in relation to its spatial distribution. Table 1 displays the population growth rates in American metropolitan statistical areas and German city regions with a population of more than one million (2010) in the 1990s and 2000s. The respective regions are geographic entities delineated by the Office of Management and Budget (OMB) and the German Federal Institute for Research on Building, Urban Affairs and Spatial Development (Bundesinstitut für Bau-, Stadt- und Raumforschung BBSR). The principal cities in the United States consistently showed population growth, while in Germany this was only the case since the 2000s. In the United States, the data bring out an uninterrupted dominance of suburbanisation, fueled by a tremendous overall population growth, while in Germany a transition into a phase of intraregional (re-) concentration is apparent in the 2000s.

Tab. 1: Population change in US metro and German city regions (with more than one million inhabitants) in the 1990s and 2000s (percentage) (own calculation based on census data)

\begin{tabular}{|c|c|c|c|c|c|c|}
\hline & \multicolumn{3}{|c|}{ 1990s } & \multicolumn{3}{|c|}{$2000 s$} \\
\hline & $\begin{array}{c}\text { Principal } \\
\text { cities }\end{array}$ & Suburbia & Region & $\begin{array}{c}\text { Principal } \\
\text { cities }\end{array}$ & Suburbia & Region \\
\hline $\begin{array}{l}\text { US Metropolitan } \\
\text { Statistical Areas }(n=50)\end{array}$ & 9.4 & 19.1 & 15.0 & 4.7 & 14.6 & 10.7 \\
\hline $\begin{array}{l}\text { German City Regions } \\
(n=14)\end{array}$ & -1.2 & 7.4 & 3.2 & 3.0 & 0.6 & 1.7 \\
\hline
\end{tabular}

Source: own calculation

An evaluation differentiated according to ring zones in the eight selected metropolitan regions shows that the highest growth rates in the American regions during both decades were predominantly focused on the outer suburban zone, which - as mentioned above - suggests sustained suburbanisation (Fig. 1a/b); an interesting outlier is the Boston region in the 2000s. Yet, it would be oversimplified to diagnose an ongoing trend of deconcentration for the US regions. The inner areas of the American regions almost invariably experienced population growth during the 1990s and this trend continued (and accelerated in many cases) during the last decade. Even the core area of the Philadelphia region, a city exposed to fundamental economic and structural change, turned from population losses during the 1990s to population gains during the 2000s. When the changes in population within the ring zones are normalised according to land area (change in population per $\mathrm{km}^{2}$ of land area) surprisingly powerful densification processes can be identified for areas close to the centre. The population density of the core of Boston rose by around 450 residents during the 2000s, while Philadelphia and Portland still registered 210 and 140 residents per square kilometer, respectively. Only in Atlanta, the core area population stagnated during this decade. 
Fig. 1a: Population change in ringzones of US metropolitan regions (percentage, 1990-2000, 2000-2010)
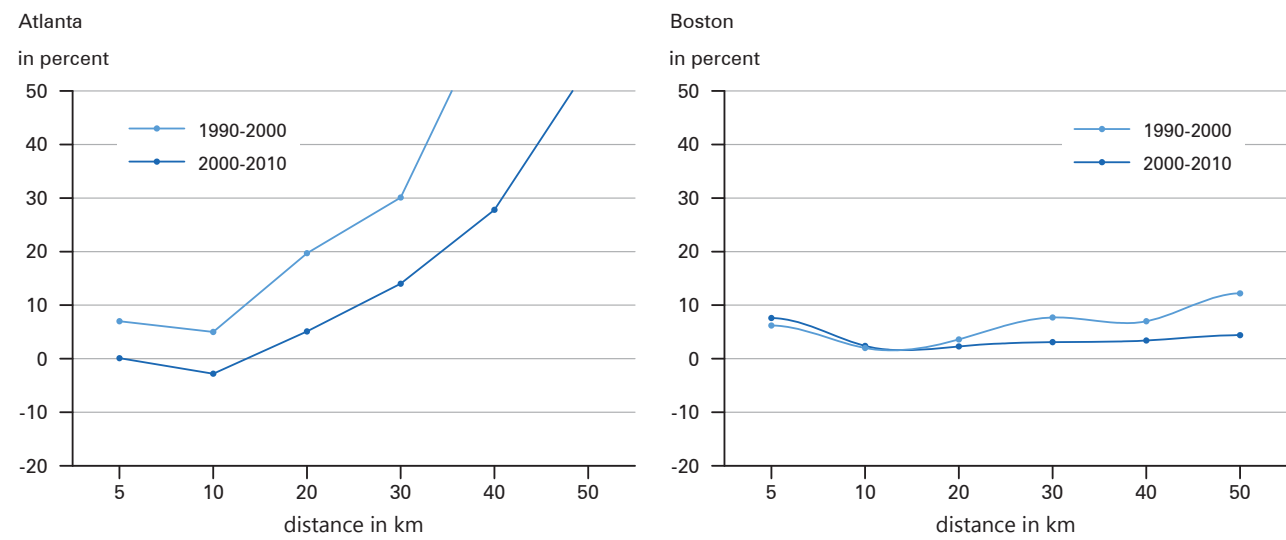

Philadelphia

Portland

in percent

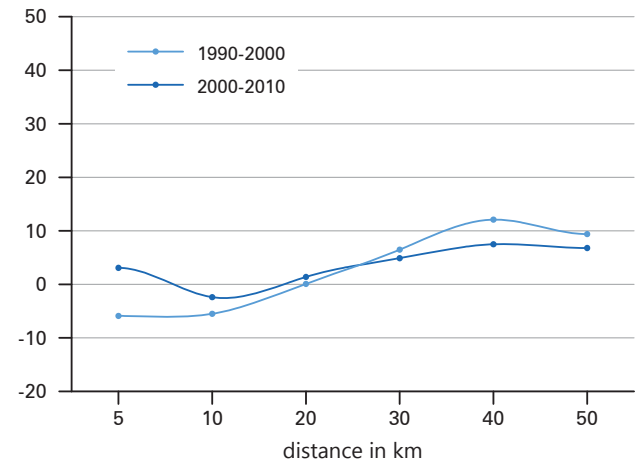

in percent

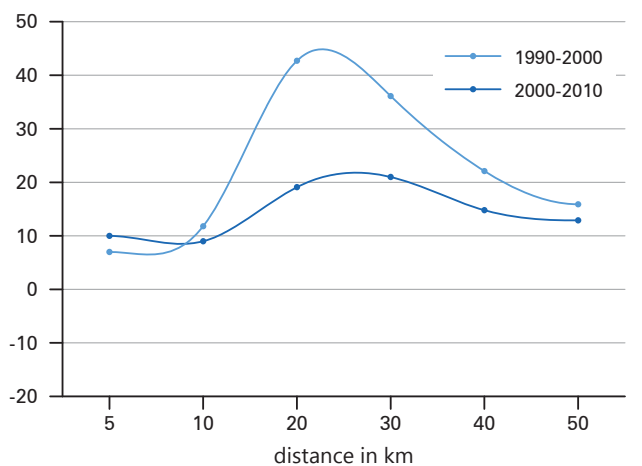

Source: own calculation

In Germany, the focal points of growth during the 1990s were also located in a certain distance to the urban cores. During the 2000s, however, the highest growth rates were achieved within the inner areas of the regions. A process of suburbanisation that stretched far into rural areas was therefore supplanted by an intraregional concentration of population. All regions considered here were characterised by strong densification processes during the 2000s within the core areas. The Munich region, with a value of 880 residents per square kilometer, stands out in particular.

To interpret the identified demographic reurbanisation processes in more detail, additional analysis differentiating age groups was conducted. ${ }^{1}$ We calculated the location quotients (LO) of different age groups indicating the structural composition

1 Further desirable analysis of population changes taking income and social status of residents into account could not be conducted due to lack of comparable data on census tract, neighbourhood and municipal level. 
Fig. 1b: Population change in ringzones of German metropolitan regions (percentage, 1990-2000, 2000-2010)

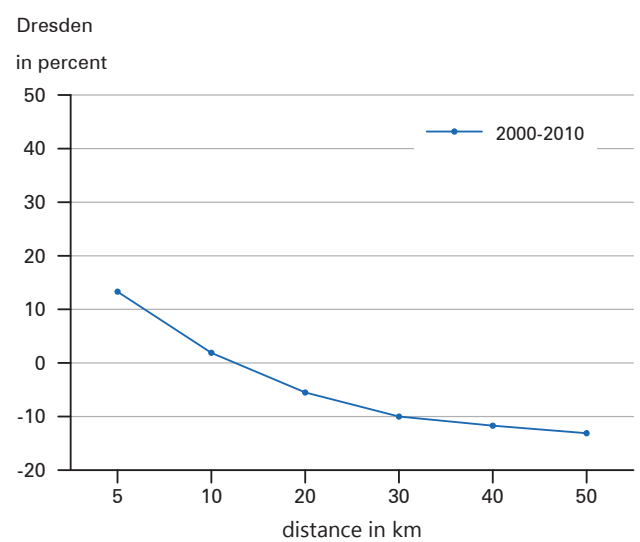

\section{Frankfurt}

in percent

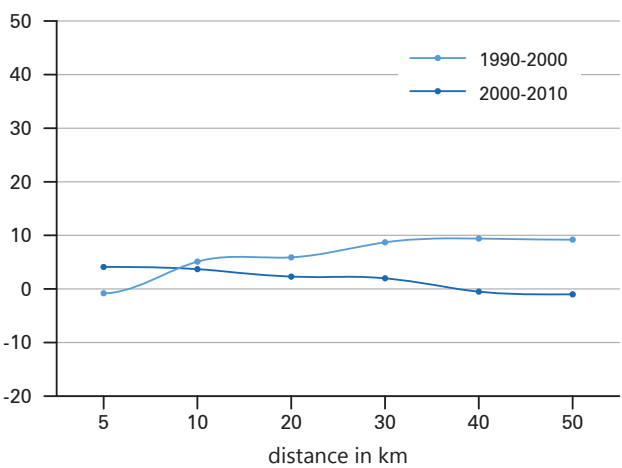

Munich

Stuttgart

in percent

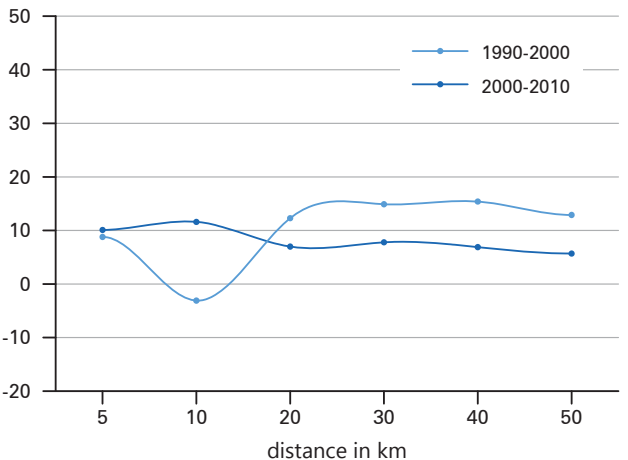

in percent

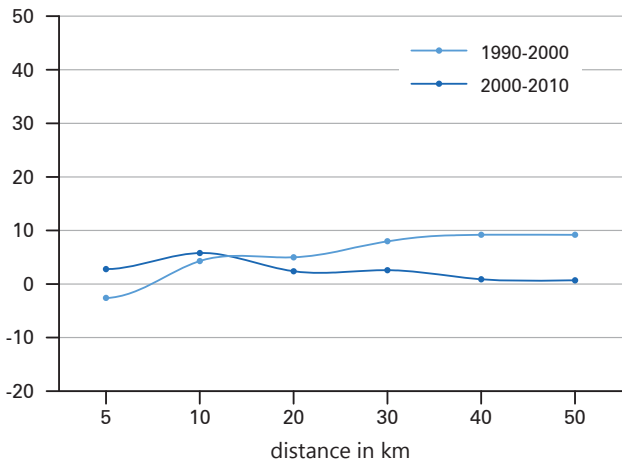

Source: own calculation

of populations according to age and its change over time. The location quotient relates the share of a demographic group (here: age group) within a territorial unit to the share of the same group across the entire region (Estiri et al. 2015). A value of 1.0 indicates that the share equals the regional mean. Values greater than 1.0 indicate a statistical overrepresentation, while values lower than 1.0 display an underrepresentation of the respective group within the considered territorial unit.

Figure $2 \mathrm{a} / \mathrm{b}$ displays the calculated values for the core areas in the US and Germany. In all of the eight regions, similar as well as divergent structures and processes of age-based segregation are revealed. Our analysis first demonstrates that younger adults at an age of higher education and career starters are continuously overrepresented in the core areas. This is expressed in high and even rising LQ values for the 18- to 24-year-olds (with the exception of Portland and Stuttgart) and 25- to 29-year-olds. Yet, a striking result is an increasing LQ value for the 30 - to 44-year-olds in the core areas of all eight regions. At the same time it becomes obvious that families with children, however, are underrepresented, as the values for the 
Fig. 2a: Location quotients of different age groups for 1990 and 2010 in core areas $(0-5 \mathrm{~km})$, USA
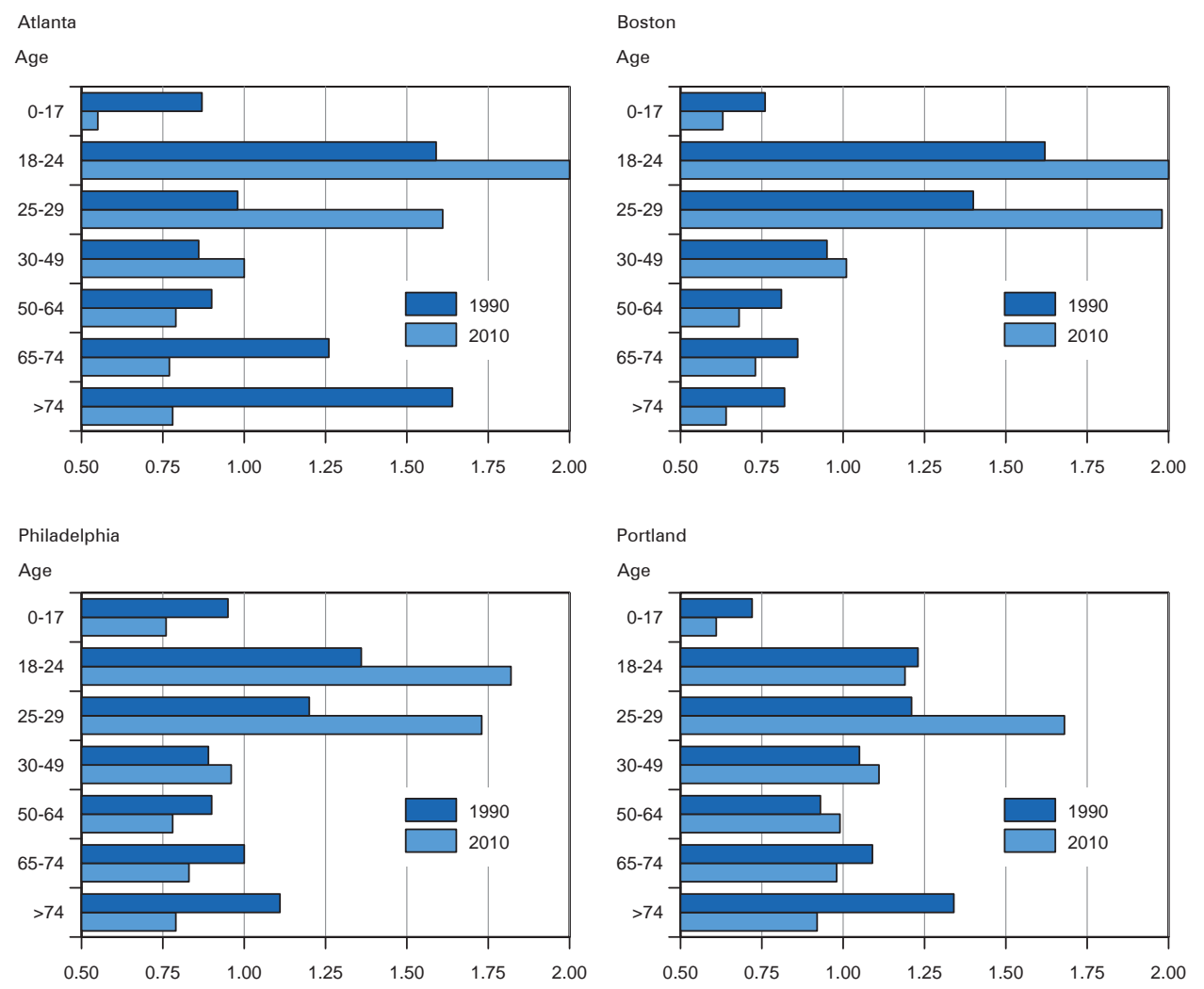

Source: own calculation

0 - to 17-year-olds show. During the last two decades, this trend intensified in the US regions, but extenuated in the German regions. The elder population (people over 64 ) is underrepresented in core areas of all regions in 2010 and the LO values have consistently decreased over time.

In sum, our analysis yields similar basic patterns on both sides of the Atlantic. Starting from a much younger population in the US than in Germany, the core areas experienced significant rejuvenation (also referred to as "young-ing" according to the Brookings Institution 2010: 83) during the 1990s and 2000s, which can primarily be attributed to gains in migration (Juday 2015; Estiri et al. 2015). Reurbanisation therefore does not just take place as residential densification in the regional centres, but is also a process of increasing age segregation. In both the American and the German context, young adults at an age of higher education (18- to 24-year-olds) and career starters (25- to 29-year-olds) are participating demographic groups in the demographic revival of inner-city areas. Our findings show, however, divergent trends for families with children. While families in the German regions appear to 
Fig. 2b: Location quotients of different age groups for 1990 and 2010 in core areas $(0-5 \mathrm{~km})$, Germany
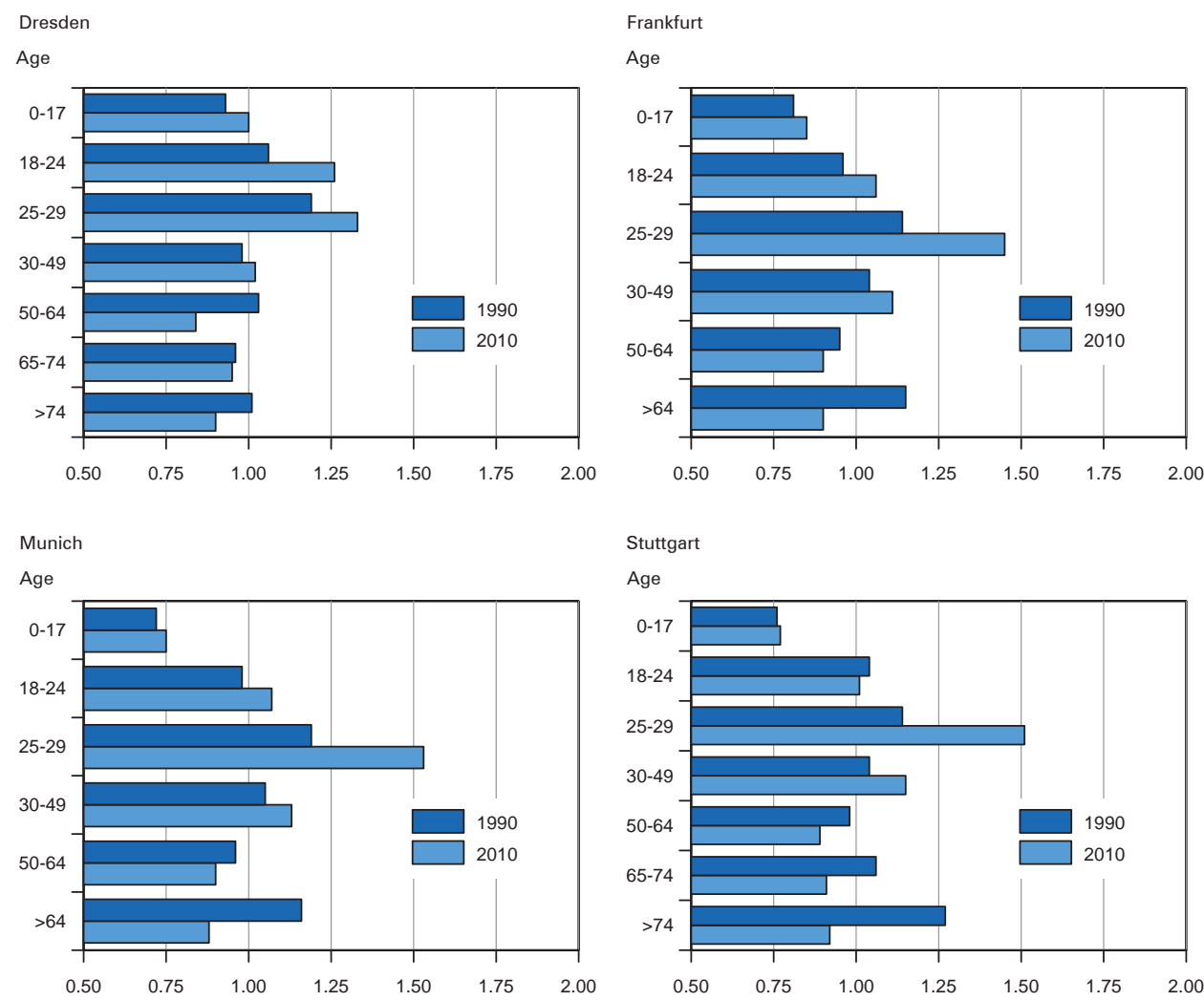

Source: own calculation

play a role in the population growth of the inner regional areas, a strong negative trend can be discerned for the American regions, based on an underrepresentation in the regional cores that was already strong in 1990.

In addition to the change of population we also analysed dynamics of housing production. Reurbanisation - according to our understanding - can only take place if new housing units are added or if existing housing units are used more efficiently (for more detail see section 3). Due to limited availability of equivalent data, we had to confine the comparison to housing construction activities as derived from changes in the housing stock. While this data does not allow differentiation between new construction and housing losses (i.e. by demolition), it is suitable to provide a rough overview on the intraregional dynamics of the housing market.

Our empirical findings cannot be described in detail here due to space restrictions. But according to a main finding the core of the examined German regions only experienced moderate increases in housing units - compared to what could have been expected from the population increases -, while "over production" of housing 
Tab. 2: Additional housing units per additional inhabitant in ringzones, 20002010

\begin{tabular}{lcccccccc}
\hline Zone & Atlanta & \multicolumn{1}{c}{ Boston } & Philadelphia & Portland & Dresden & Frankfurt & Munich & Stuttgart \\
\hline $0-5$ & 5.0 & 0.6 & -1.1 & 0.7 & 0.0 & 0.6 & 0.3 & 0.4 \\
$5-10$ & -1.6 & 1.0 & 3.8 & 0.6 & 1.8 & 1.0 & 0.6 & 0.5 \\
$10-20$ & 1.6 & 0.9 & 0.9 & 0.5 & $-*$ & 1.3 & 0.7 & 1.3 \\
$20-30$ & 0.7 & 1.1 & 0.8 & 0.5 & $-*$ & 1.4 & 0.7 & 1.2 \\
$30-40$ & 0.5 & 0.9 & 0.6 & 1.0 & 0.0 & $-*$ & 0.7 & 3.2 \\
$40-50$ & 0.4 & 0.8 & 0.6 & 0.9 & 0.0 & $-*$ & 0.8 & 3.7 \\
Region & 0.6 & 0.9 & 0.7 & 0.6 & $-*$ & 1.2 & 0.5 & 1.2 \\
\hline
\end{tabular}

* negative population change

Source: own calculation

took place in the more suburban zones (Table 2). Especially for the core areas, a mismatch of demographic growth and housing production can be diagnosed. In these regions, reurbanisation processes to the extent pictured above could only rendered possible by a reduction in floor area consumption. In contrast, reurbanisation in American metro regions is stronger linked to expanding housing markets in core areas. Here, the real estate market dominated by private enterprises responded to the obviously growing demand for inner city living. Additionally, significant planning interventions during the 1990s (such as up-zoning, introduction of rail-based transport, master planning for inner city conversion sites) paved the way for these developments.

Yet, these findings do not explain the phenomenon of "childless reurbanisation" (Siedentop et al. 2017) that we found in the US regions and the fact that families obviously took part in the process of inner-city densification in German metro regions. It can be assumed that the regional housing markets in the US and Germany offer varying options for "family living", and that cultural differences in acceptance of these options appear, that may be interlinked with questions of price and affordability. The poor reputation of public schools in American central cities might also play a role here. Some authors also point to the small unit sizes of new inner city housing that makes them more suitable for childless households (Moos 2015), whereas others found evidence for a more family-friendly housing construction in German cities, especially in the owner-occupied segment (Frank 2016). Further inquiry on the background of these divergent patterns is presented in the following chapter.

\section{Comparing Reurbanisation in Stuttgart (Germany) and Portland (US)}

The previous section provided evidence for a general trend towards reurbannisation in US and German metro areas - here understood as population growth in 
urban cores and densification. At the same time, we observed a large variety of demographic and housing trajectories in terms of spatial and temporal manifestations. In the following section we will analyse the interrelation of demographic trajectories and housing production in two (re-) growing cities - Stuttgart and Portland - in more detail.

\subsection{Reurbanisation and housing}

Our case studies focus on the relation between reurbanisation and housing production and its small scale manifestations within the inner city areas. We chose the cities of Portland (Oregon, USA) and Stuttgart. The reasons for this case selection will be unfold in the next section (3.2). The analysis is driven by the following questions which have so far largely been ignored in empiricial research on reurbanisation: How is population growth connected with housing construction activities in central city neighbourhoods (section 3.3)? How do regional and municipal governance and policies contribute to the emergence of reurbanisation (section 3.4)? What kind of changes in the built environment can be seen at neighbourhood level (section 3.5)? Our quantitative analysis was based on a small-scale examination of census data (from 1980 to 2010, with an update for more recent developments). We supplemented this data part by analysing city-specific research literature, market research literature as well as policy documents and by conducting expert interviews and site visits in both cities.

\subsection{Selection of case studies and methodology}

As shown above, a considerable number of city regions in Germany and metropolitan areas in the US experienced population growth in their core areas during the 1990s and 2000s, but the degree as well as the spatial and temporal patterns of urban growth widely varied. Therefore, the panel for selecting single case studies is per se confined and the selected cases do by no means represent the development trajectories of the entire country, yet they cover an important section. Comparing development trends in two cities may contribute to understanding local expressions of the supposedly global trend of reurbanisation, to identifying driving forces, and to reviewing the scope of policy and planning efforts.

Stuttgart and Portland qualified for further examination because they are not only part of the panel of conurbations that currently witness population growth and a large demand for housing in their cores, but also because they both look back on a long history of a comparably strict regional and local regulatory setting that focuses on the reduction of land consumption and revitalisation of the urban core (Abbott 2004; Harlander/Jessen 2001; Jessen/Mayer 2010). It can therefore be expected that reurbanisation is, at least partly, the desired outcome of planning, governance and regulation efforts in both cities, or as Engler (2013: 23) puts it, reurbanisation was "planned". We are fully aware that the national contexts of both case studies vary considerably. Comparative studies on national contexts (among others: DiGaetano/Strom 2003; Sellers 2005) have stressed that urban governance 
in the US is predominantly characterised by its "privatist", and in Germany by its "statist" culture (DiGaetano/Strom 2003: 375). Though the overall cultures of urban governance contrast sharply due to different historical paths, there are very important common characteristics that lie in the "devolved intergovernmental systems" (DiGaetano/Strom 2003: 375). In both national contexts, the municipalities, representing the local level of the national governmental system, boast a high degree of political autonomy, compared to other western countries like France or the United Kingdom. Therefore, municipalities can adopt individual modes of urban governance even within the same national context. These essentials of urban comparative research are not subject of our in-depth study in the sense of a full-fledged comparative analysis of urban governance in both countries, but they form the basis for our selection of case studies and the interpretation of the findings.

In contrast to the choice of metro regions in section 2, the two study regions were selected according to the logic of the most similar systems. The idea is to compare objects (in this case, regions) that share important characteristics (in this case: population size, economic and spatial characteristics), which allows for controlling explanatory context factors (Pierre 2005: 454-455). In sum, this part of the study focuses on finding out why reurbanisation processes are different in two rather similar regions. The major similar traits of the selected case study regions that are relevant for the phenomenon under examination are:

- Size and regional importance: Both, the city of Portland (583,776 inhabitants in 2011) and the city of Stuttgart (585,890 inhabitants in 2010) are the largest cities in the state they are located in (Oregon/Baden-Wuerttemberg). They both form the centre of a surrounding metropolitan region of similar size (Greater Portland: $2.07 \mathrm{~m}$ inhabitants in 2011, Greater Stuttgart Region: 2.62 $\mathrm{m}$ inhabitants in 2010).

- Economic base and development perspectives: Both metro regions are known for a strong, manufacturing-based, export-oriented economy (machine building, wood processing, electronics, and sportswear in Portland; car industry and machine building in Stuttgart) with a dynamic and stable development of jobs during the last decades.

- Early adoption of pro-active spatial regulation of urban and regional development: Since 1972 (Downtown Plan), the city of Portland undertakes substantial inner city regeneration efforts. Since 1979, the regional planning alliance Portland Metro steers regional development via an Urban Growth Boundary and other tools. Since 1974, the city of Stuttgart institutionalised and formalised inner city regeneration efforts. In 1976, an inter-municipal cooperation for land use planning was established between Stuttgart and the neighbouring municipalities. It was replaced by a regional planning alliance Verband Region Stuttgart and a regional parliament in 1994 that steer development via a Regionalplan.

\subsection{Reurbanisation and Housing Market Development in Portland and Stuttgart}

First, it has to be stated that reurbanisation - understood as an increase in inner city population - has been reported for both Portland (Abbott 2004; Birch 2005; Lewis 
et al. 2013) and Stuttgart (Haußmann 2007; Brachat-Schwarz 2008; Schmitz-Veltin 2014; Brombach et al. 2014) during the last decade. Recent studies show that labour and education driven migration seems to have the most substantial impact on reurbanisation in both Portland (Schrock/Jurjevich 2012) and Stuttgart (Schmitz-Veltin 2014: 10). In both cities, dynamics of housing markets play a crucial role in fostering (and in some cases also slowing down) processes of reurbanisation. At the same time, structural differences in terms of homeownership rates (much lower in Stuttgart) and dominating housing types (apartments in Stuttgart, single family homes in Portland) have to be taken into account.

In our research, in a first step, population and housing developments were compared for both cities by using small-scale census data for the years 1980, 1990, 2000, 2010 and 2015. In analogy to the ring-zone model used in section 2, figures were analysed for three spatial units (Fig. 3): (1) the entire municipality (borders as of 2010), (2) the core area, a circle with 5 kilometres radius around the city hall, and (3) the central city, as it was outlined in important planning documents of both cities. ${ }^{2}$ In a second step, the calculated numbers were set in context to findings that were derived from qualitative interviews, document analysis and site visits in order to interpret the developments against the background of local urban policies, planning and regeneration efforts.

The figures in table 3 show the absolute and relative population changes for the entire municipality, the core and the central city of Stuttgart and of Portland between 1980 and 2010/15. Although both, Portland and Stuttgart, since 2000, report similar population sizes within their city borders, the number of residents in the core of Portland $(160,000$ inhabitants in 2010) is substantially smaller than in Stuttgart $(270,000$ inhabitants in 2010$)$. Whereas almost half of the city population (48.4 percent) of Stuttgart live in the core area in 2010, only 27.3 percent do so in Portland. Only 6.4 percent of Portland's citywide population live in the central city of Portland, whereas in Stuttgart 26.4 percent do so (2010).

When looking at the population development rates in both cities, a first obvious interpretation is that reurbanisation - defined as population growth in the inner areas of the city-occurred earlier and more pronounced in Portland, with a clear lead of the central city, where growth rates exceeded citywide growth rates in each decade. In Stuttgart, the classic pattern of "inner city flight" prevailed during the 1980s and 1990s. During the 2000s, a trend reversal towards a citywide population increase took place, yet on a level of very modest growth rates compared to Portland and not pioneered by developments in the central areas of the city. Only during the last half-decade (2010-15) the modest population increases witnessed after 2000 clearly intensified both citywide and in the core areas of Stuttgart. Yet, when look-

2 Statistical sub-units (census tracts for Portland, Stadtteile and Stadtviertel for Stuttgart) were merged to approximately rebuild these perimeters for data analysis. Both cities exceeded the number of 600,000 inhabitants after 2010, with Portland starting from a much lower population number. Constant growth of population occured in Portland during each decade, whereas in Stuttgart the process of population decrease only reversed during the 2000s and gained momentum after 2010 


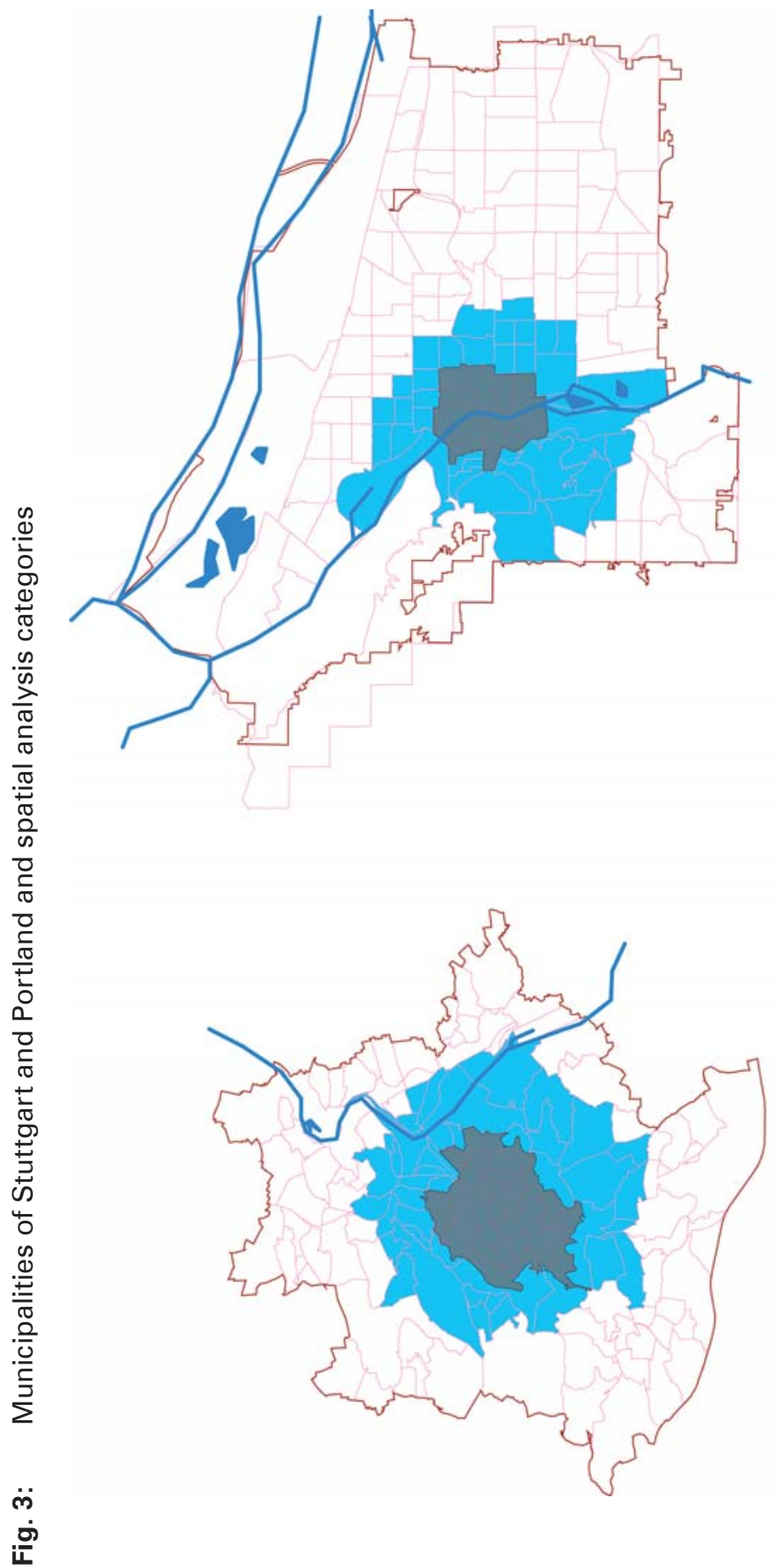

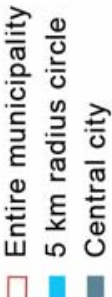

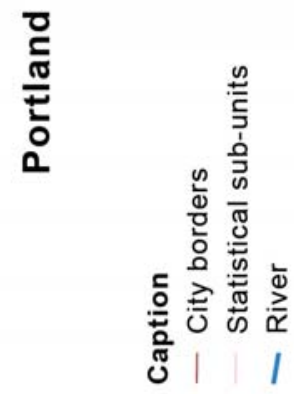

紊

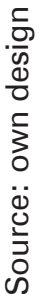




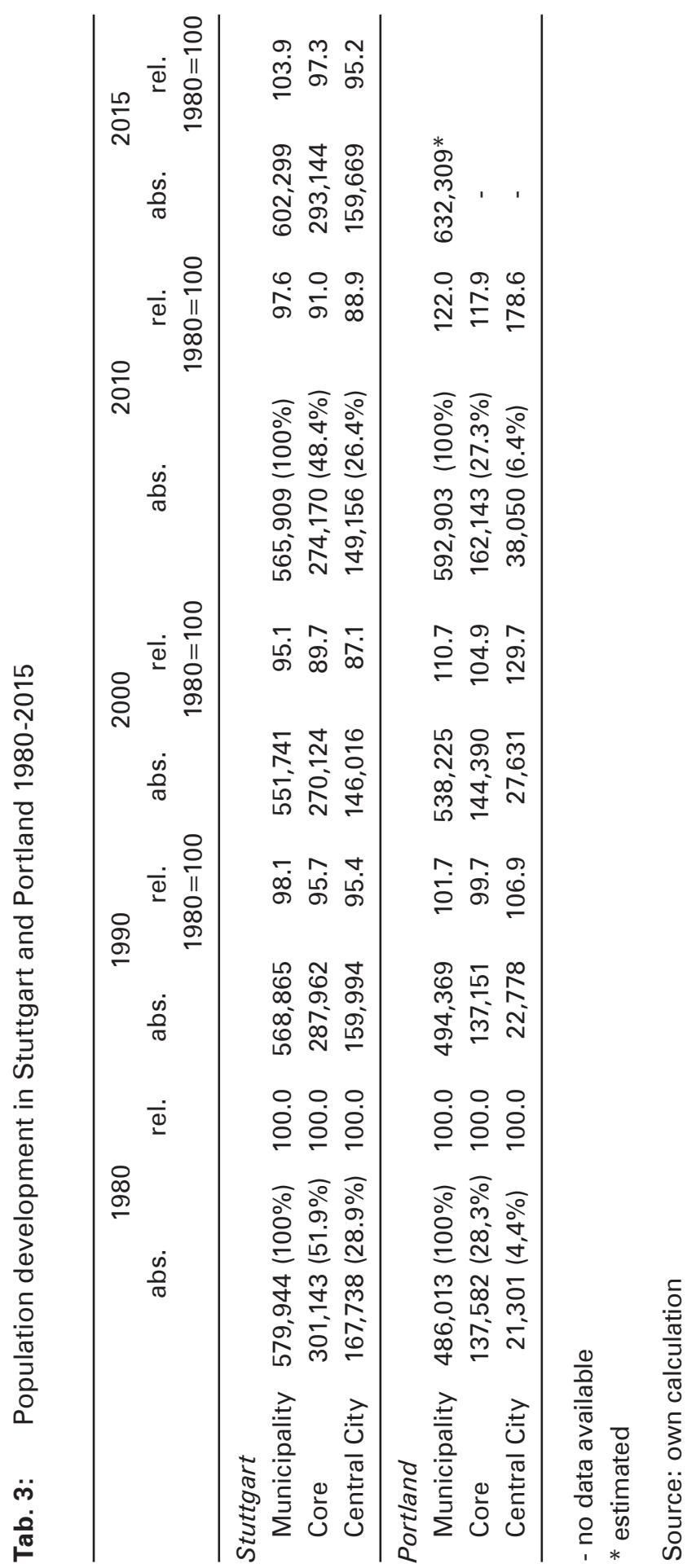


ing at the latest developments in each city, it has to be stated that while Portland's central city had an impressive population growth rate of 37.7 percent during the 2000 s, the absolute population gain of around 10,000 inhabitants almost equals the population gain Stuttgart's central city has experienced later and in shorter time, between 2010 and 2015.

Comparing the development of both cities, Portland appears as a growing city since the 1990s, with peak growth rates in its centre. Stuttgart joined the growth path later - after 2000 - and experienced much more modest population growth rates during the 2000s than Portland. While Portland's central city faced impressive growth of residents of more than 37 percent, the growth rates in Stuttgart's central city only slightly exceeded the citywide ones during the last half-decade (2010-15), before that, they mostly remained under 5 percent. The development of Portland's less populated but rapidly growing central city seems to disconnect from citywide trends as growth rates here exceed the citywide growth rates by far. On one hand, this growth mirrors a "residentialisation" of the urban core that had previously not been dominated by housing, but rather by businesses and other uses (Central Business District (CBD)). Similar observations have been made in other large downtown areas in the US like Atlanta, Miami and others (Sohmer/Lang 2001; Birch 2005: 5).

The most striking difference between the two cities is the population density (calculated as residents per hectare; Fig. 4): In 1980, Stuttgart's population density is almost three times higher than in Portland; even after 2000 it is still almost twice as high as in Portland. While Portland has started from a very low population density level compared to Stuttgart, it has seen constant densification since 1980, ${ }^{3}$ whereas for Stuttgart, densification could only be witnessed after 2000, but the density value of 2010 even exceeded the one of 1980 . Although both city cores are denser than the respective entire municipality, the density level in Portland's city core did not reach Stuttgart's citywide density levels at any time.

The patterns of housing development in both cities resemble those of the population increases, but there are also striking differences: In Stuttgart, a loss of housing units never occured, while Portland's central city experienced a 5.8 percent loss of housing units during the $1980 \mathrm{~s}^{4}$ While Portland's population growth, since the 1990s, was accompanied by equally high increases in housing units for each analy-

3 In our research, we used the municipal borders of 2010 as a constant spatial delineation for analysis. In reality, Portland had incorporated large areas of land during the 1980s, 1990s and 2000 s, so the actual densification effect must be assumed to have been less dramatic than these calculations suggest.

4 According to the Municipal Statistical Office of Stuttgart (Interview 06/10/2015), there may be undercounted losses of housing units in the data for Stuttgart, because there is no obligation to report cases that do not require an official legal permit, such as small scale changes of use (i.e. transforming an apartment in a larger building into an office space). On the other hand, the methods of how to count vacant residential buildings seem not to be entirely consistent between different US census generations and counties (the territory of the city of Portland covers three different counties), which may have influenced the housing data for Portland. It is more likely though that the housing losses in Portland mirror the comprehensive transformation processes in the Pearl District that started with demolition during the 1980s. 
Fig. 4: Development of population density in Stuttgart and Portland 1980-2015

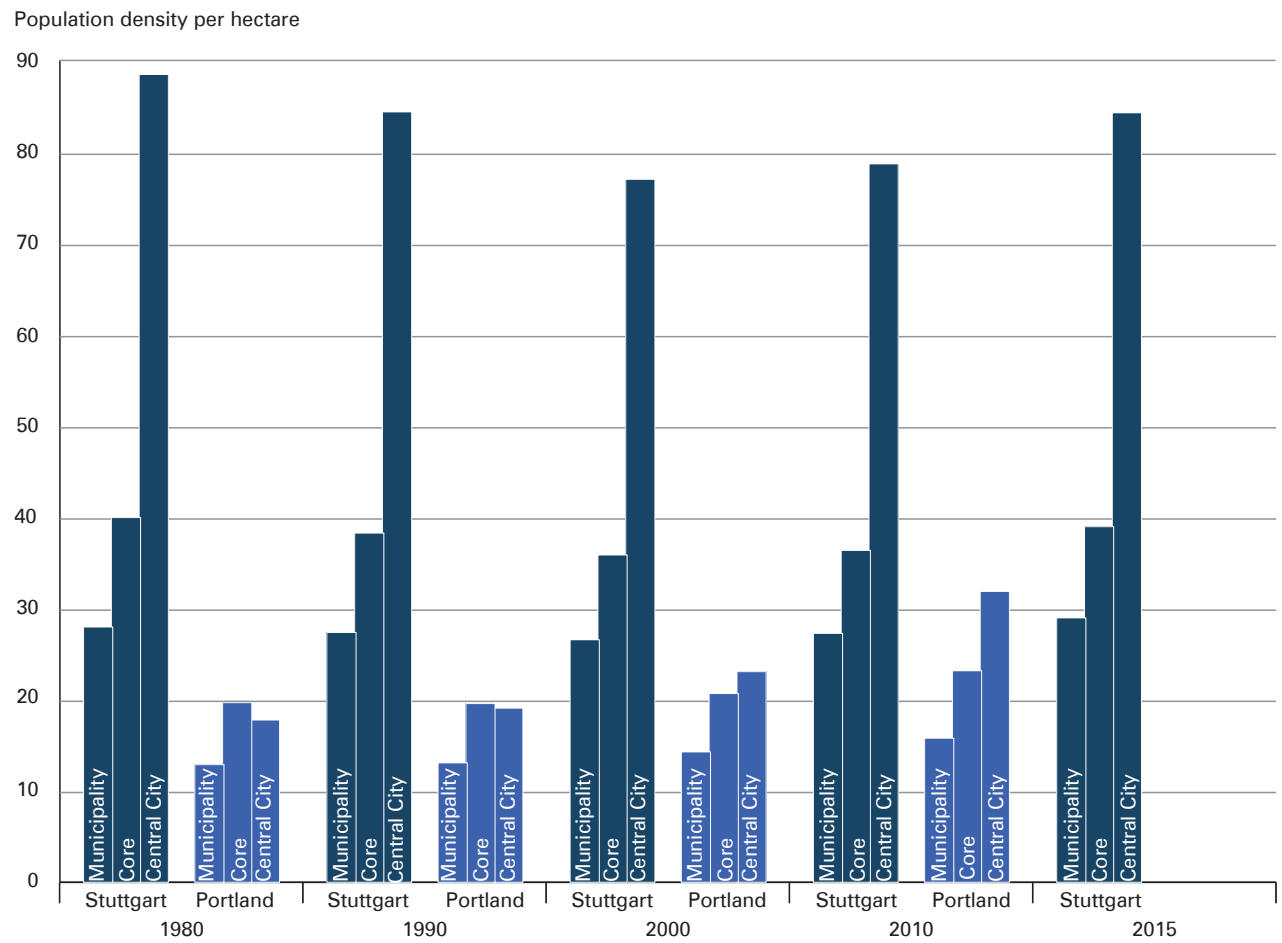

Source: own design

sis phase (citywide, core, central city), this was by no means the case in Stuttgart. Especially in the central city, the development of population and housing seem to drift apart with the highest population growth rates and the lowest housing unit development rates between 2010 and 2015. This seemingly paradox pattern was also observed in other large German cities and it characterises the entire German housing market (see section 2 and Henger et al. 2015).

In 2010, 51 percent of Stuttgart's housing stock is located in the core area, but only 33.5 percent of Portland's housing stock. In both city cores, housing units were on average occupied by fewer users than in the entire municipality, which indicates smaller household sizes in these centrally located areas. At the same time, 28.8 percent of Stuttgart's citywide housing units are located in the central city, but only 9.5 percent of Portland's citywide housing units.

Comparing the housing occupancy rate (Fig. 5) describing the average number of persons living in one housing unit in a certain area, Portland city's housing units are occupied by slightly more persons than Stuttgart's. This is in line with average American household sizes being larger than German ones. During the 1980s, 1990s and 2000s, decreasing occupancy rates (calculated average number of residents per housing unit) were an overall continuous trend for Portland and Stuttgart that 
Fig. 5: Development of occupancy rates in Stuttgart and Portland 1980-2015

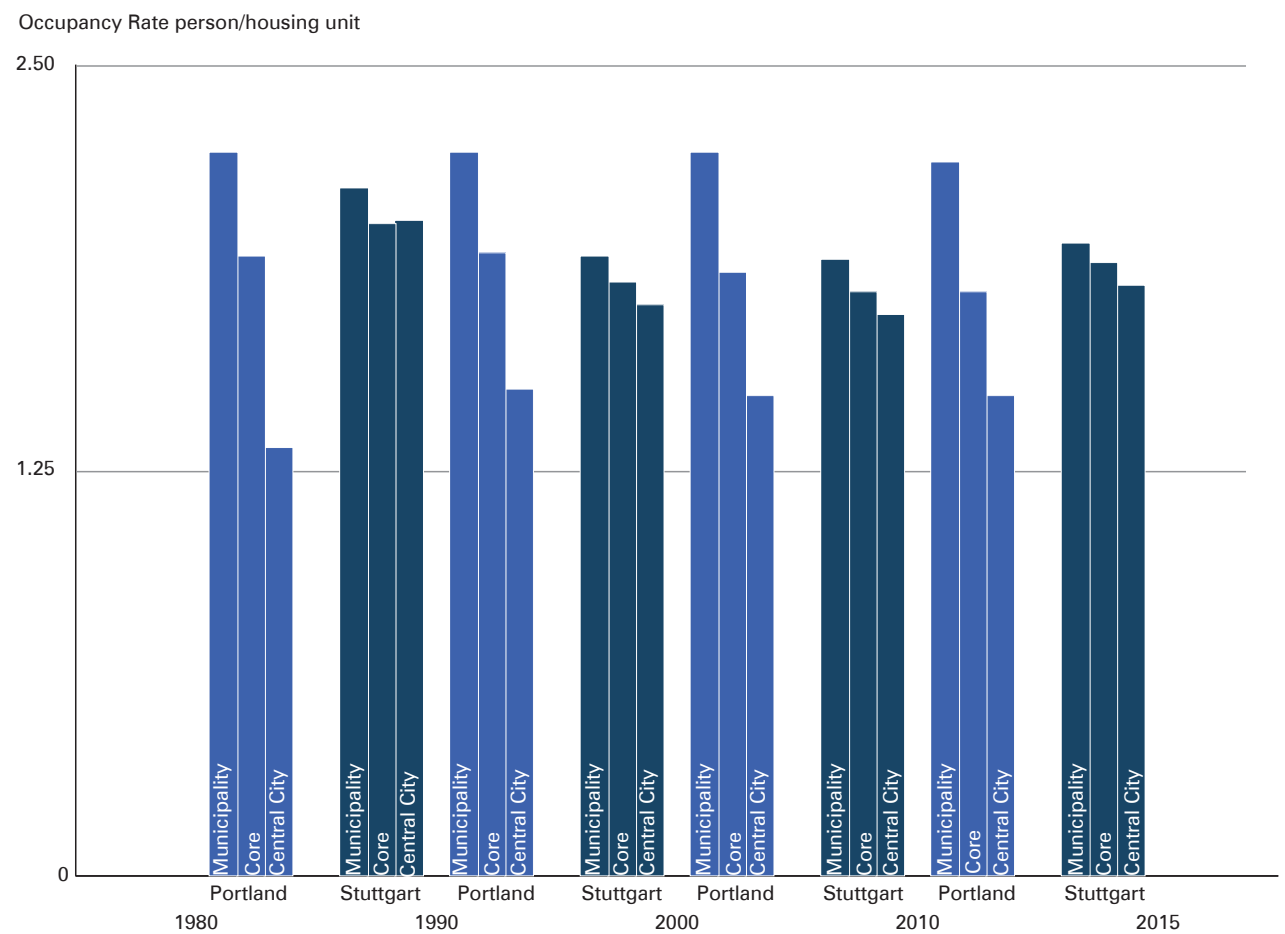

Source: own design

resulted from increasing floor space area consumption and decreasing household sizes. But recently, the persistently declining housing production seems to have led to increasing occupancy rates in Stuttgart. Here, city dwellers seem to "close ranks" - a phenomenon that cannot be observed in Portland and was not observed in Stuttgart before 2010.

To sum up findings, Stuttgart is "lagging behind" in development compared to Portland, as population gains did not set in sooner than during the 2000s and gained momentum after 2010. Development rates in the central areas of the city are more modest and more or less congruent with citywide development rates. One can interpret the development of Stuttgart as experiencing a "renaissance" in the sense that the city is "returning" to some of its characteristics of the 1980s in regard to population size, density and housing occupancy rates. Yet, a notably opposing trend is the decrease in housing construction efforts in Stuttgart's centre since 1990. In Portland, since the 1990s, central city development dynamics outperform the citywide ones, with a development of occupancy rates and population density that clearly deviates from citywide values after 2000. 


\subsection{Regulatory setting and contribution of planning}

In this section, we examine wether public policies have contributed to the partly convergent and divergent patterns of reurbanisation in both cities. In order to analyse the governance settings and the contribution of planning policies in both regions, we used a multi-scalar approach, as recommended by Getimis (2012). In interviews with local experts we reflected the relevance and effectiveness of the planning authorities, strategies and projects and therefore critically evaluated "the reality" of the two planning systems (Stead/Nadin 2009).

In both cities, the political goal of reducing land consumption and reviving the central city as a place for living was voiced very early (1960s and 1970s). For both regions, important legal foundations became enacted on state level during the $1970 \mathrm{~s}$ that allowed for subsequent implementation of comprehensive regional and municipal growth management strategies. Powerful institutions were established that are responsible for regional planning and development (Metro in Portland, Verband Region Stuttgart in Stuttgart). Yet, it was a complex interplay between different levels of governance (local, municipal, regional, state) and constant adjustment of goals, policies and foci were necessary to steer this process during the following 40 to 50 years. In both city regions, counter flow principles between local, regional and state level helped to harmonise planning and development strategies.

In Stuttgart, municipal efforts in regaining a high quality of life for inner city dwellers set in very early, were continuously funded (mainly by state programmes for urban regeneration) and focussed on redesigning oversized traffic infrastructures and promoting in-fill development. In 1994, a clear rejection of further greenfield development was stipulated in the municipal land use plan and led to prioritisation of redevelopment and densification of built-up areas. This political course has since then not been fundamentally changed even though it was challenged many times by the delays, funding problems and controversies around the major inner city redevelopment project "Stuttgart 21", the restructuring of Stuttgart's main station and its surroundings.

In Portland, the demolition of an inner city highway was the starting point for a long-term city development process that centred on comprehensive downtown revitalisation by waterfront redevelopment and the re-introduction of rail-based public transport. Municipal regeneration efforts were backed up by regional growth management (introduction of an Urban Growth Boundary UGB), state-initiated funding opportunities (via Tax Increment Financing TIF) and a pro-active involvement of citizens (f.e. via neighbourhood associations). Investment was mainly concentrated in the so-called "Pearl District", a centrally located former railyard and warehouse district.

Analysing the governance and planning efforts of the two case study regions revealed that an abundance of tools, concepts and programmes were being applied during the last decades that focused on improving the structure, quality and connectivity of the central city and increasing residential offers here. In this sense, reurbanisation cannot be seen as a predominantly market-driven phenomenon like some authors suggest (Krätke 2014; van Criekingen 2009). In Stuttgart and Portland, 
Tab. 5: Intervention modes of public authorities

\begin{tabular}{|c|c|}
\hline Stimulating investment & $\begin{array}{l}\text { Providing public subsidies, tax and fee charge exempts, } \\
\text { density and height bonuses, improvement of infrastructure, } \\
\text { levering resources via Tax Increment Financing (TIF) or } \\
\text { Städtebauförderung }\end{array}$ \\
\hline Directing investment & $\begin{array}{l}\text { Prioritisation of selected areas by overall plans and concepts, } \\
\text { e.g. "Metro Growth Concept", "Central City Plan" (Portland) } \\
\text { "Gebietstypenplan", "Grünes U“ (Stuttgart), upzoning of } \\
\text { selected areas. }\end{array}$ \\
\hline Skimming investment & $\begin{array}{l}\text { Skimming of increment and appropriation of funds for } \\
\text { public interests such as affordable housing, eg. via "SIM" } \\
\text { (Stuttgarter Innenentwicklungsmodell) and "TIF housing set } \\
\text { aside" (Portland). }\end{array}$ \\
\hline Qualifying investment & $\begin{array}{l}\text { Safeguarding spatial quality standards (e.g. provision } \\
\text { of playgrounds and child care facilities) of new urban } \\
\text { development, e.g. via concept selection procedures and } \\
\text { municipal contracting criteria, state building codes, urban } \\
\text { development contracts, Charettes, citizen participation. }\end{array}$ \\
\hline Confining investment & $\begin{array}{l}\text { Restricting new development in order to protect public } \\
\text { interests, e.g. by downzoning selected areas, limiting } \\
\text { building heights, mandatory quotas for affordable housing, } \\
\text { securing ways of right and preserving view axes, nature and } \\
\text { monument protection, development freezes, preservation } \\
\text { statutes. }\end{array}$ \\
\hline
\end{tabular}

Source: own design

public authorities, during each decade, "prepared the ground" for development and, today, find themselves in the sometimes contradicting role of - simultaneously or consecutively - promoting, stimulating, permitting, distributing and controlling central city growth and the related socio-demographic, economic and environmental aspects (Tab. 5).

\subsection{Reurbanisation on neighbourhood level - Modes of growth}

Most theories on reurbanisation point out that various social groups, differing in age, status, and income, contribute to the population growth in the core city: inmigrants, young urban professionals, silver agers, students and others. Though it is highly plausible that these groups find themselves in different parts of the innercity, empirical research on reurbanisation has given only little notice to the fact that urban districts may participate in or contribute very differently to the process of reurbanisation, both in intensity and in form. Only very few empirical studies adressed the small-scale manifestation of reurbanisation or even came up with some kind of typology on a neighbourhood level (for exceptions see Heinig/Herfert 2012 for the city of Leipzig; Meng et al. 2008 for the city of Mannheim; Mulherin/Howell 2012 for the City of Los Angeles). Obviously, the large scale urban regeneration projects on former industrial wasteland were very important drivers of reurbanisation processes, but detailed analyses have shown that built-up districts - even suburban in 
character - experienced population growth as well, as Koll-Schretzenmayr/Kramp (2010) proved for the city of Zurich.

Stuttgart's and Portland's central cities obviously differ from each other, not only in regard to size and density as mentioned above, but also in regard to building structure, functional and land use patterns. Both central cities contain the downtown and immediately adjacent neighbourhoods that developed in the pre-war era: in Portland, this is the CBD with its Southwestern settlement expansions and the so-called "streetcar-suburbs" stretching out to the Eastern border of the Willamette River. Stuttgart's much older historic city centre expanded into urban extensions around the city centre called "Gründerzeitgebiete" and less dense and more noble hillside construction called "Halbhöhenlagen". Today, both central cities encompass large urban redevelopment areas. In case of Portland, the so-called "Pearl District" at the Northwestern tip of the CBD is a former warehouse and railway area that underwent major transformation since the 1990s. "Stuttgart 21 " is a major urban redevelopment and infrastructure project to restructure Stuttgart's main train station and its surroundings. It is expected to produce more than 7,000 new housing units until 2020.

It has been shown that in Portland and Stuttgart, an increasing number of people live in the central city since 2000 and that new housing construction has layed the foundation for this development. During our small-scale analysis it became apparent that neighbourhoods in both cities contribute in very distinct ways and degrees to central city growth: For example, urban transformation areas accounted for substantial population gains, driven by massive housing production. In contrast, built-up neighbourhoods experience growth on a middle-range scale either by accomodating more inhabitants within the existing housing stock or by expanding the housing offer via smaller "patches" of infill development. Local growth rates may outperform the city average or stay below it, which is an indicator for the "speed" of growth taking place. Sometimes, the housing stock is growing faster than the local population, sometimes it is the other way round. And some areas in the central city, even if they are bordering hotspots of development, do not experience any population nor housing unit increases at all.

In order to attain a differentiated picture of the relationship between population development and housing production, growth rates of both core areas $(5 \mathrm{~km}$ radius circle around the city hall) were analysed for the decade 2000-2010 on a small-scale level. ${ }^{5}$ Five different "calculational" modes of growth have been identified, that are

5 For Portland, the analysis is based on 27 neighbourhoods as spatial units (by using the values for the underlying census tracts), in Stuttgart, 70 "Stadtteile" (urban districts) are taken into account (by using municipal data). 
illustrated in the following by local spatial impressions, development projects and housing types (Fig. 6): ${ }^{6}$

(1) Population-led growth: Here, population growth rates exceed housing growth rates and occupancy rates increase. For example, in both cities, the universities experienced an increase in student numbers that were partly accommodated in new dorms ${ }^{7}$ in downtown neighbourhoods such as "University District" in Portland or "Kernerviertel" in Stuttgart. Population-led growth is more common in Stuttgart than in Portland (24 districts versus 10 neighbourhoods). Most of the neighbourhoods in this mode experience "fast growth" (population growth rates above city average), only a minority "slow growth" (population growth rates below city average).

(2) Construction-led growth: In this mode, the increase in housing units exceeds population growth rates while occupancy rates decrease. This is true for 15 districts in Stuttgart and 12 neighbourhoods in Portland that partly experience "fast growth", partly "slow growth". In Stuttgart, neighbourhoods in this mode cannot be found in the immediate centre, but at the outer edge of the core. In Portland, large centrally located urban regeneration areas converted into new mixed-use neighbourhoods such as the "Pearl District" or "South Waterfront". Here, exclusive residential high-rise developments emerge on former brownfields.

In Portland's historic "streetcar-suburbs", densification becomes visible along the major commercial arterials in the neighbourhood. Here, former single-storey commercial buildings or a row of small single-family homes are replaced by 5 -storey apartment buildings, often containing several small housing units (studios, 1-2 bedrooms). The new buildings clearly differ from the existing fine-grain building structure; often there are shops or restaurants at ground level.

(3) Growth without construction: In four districts in Stuttgart and in one neighbourhood in Portland, population increases while the total number of housing units decreases - therefore, occupancy rates increase. These areas are mostly built-up areas such as the Heusteigviertel in Stuttgart or Laurelhurst in Portland, where residents are "closing ranks". In Stuttgart's dense inner city

6 These findings are based on a comprehensive review of around 150 new housing projects with more than 15,000 housing units that have been built, were under construction or approved between 2000 and March 2014 in the core cities of Stuttgart and Portland. They were collected by analyzing real estate listings (local newspaper and websites), market reports, developers' and city planning websites as well as documents and evidence from experts during interviews. Most of these projects were visited on site and documented by photographs. The average project sizes were considerably larger in Portland (146 units per project) than in Stuttgart (65 units per project).

7 Dorms are not counted as "housing units" in municipal housing statistics. 

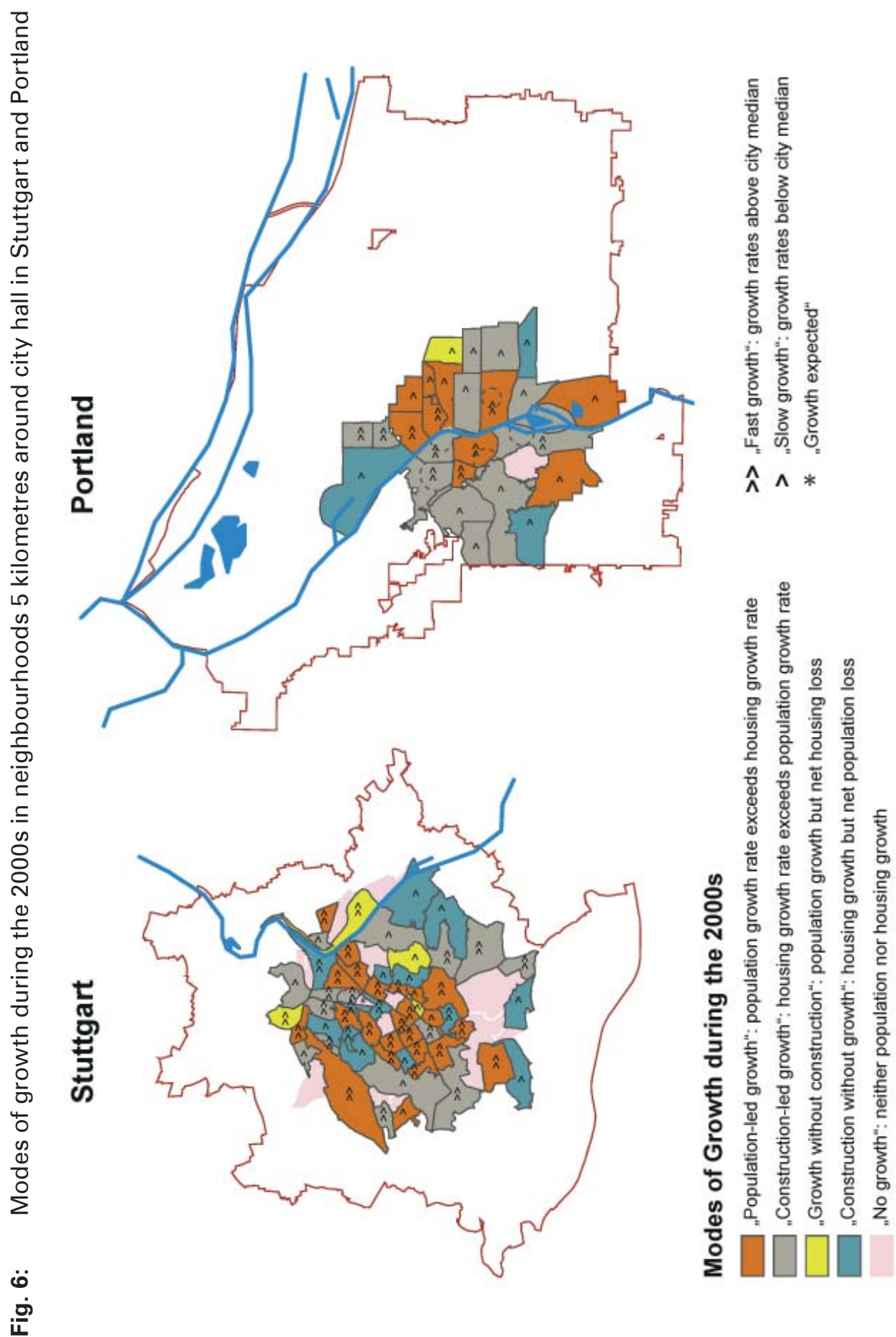

$\frac{5}{0}$
$\frac{0}{0}$
$\frac{1}{3}$
0
0
0
0
0 
neighbourhoods, some smaller building annexes can be identified visually. But other measures such as attic conversions, changes of use (i.e. former office unit is turned into an apartment), or splitting a large housing unit into two smaller units are hardly visible from the outside. Often, the population gain is accompanied by no construction measures at all. In Portland, small-scale residential development can also be observed in the form of additional small housing units on existing residential lots (the so-called ADUs - accessory dwelling units, sometimes also called "granny flats"). They are encouraged by municipal regulation, as they are seen as a non-obtrusive and sustainable form of accomodating population growth in built-up neighbourhoods.

(4) Construction without growth: In these areas, the number of housing units increases, but the number of inhabitants decreases, therefore, occupancy rates drop (true for 14 districts in Stuttgart, 3 neighbourhoods in Portland). Here, predominantly "slow growth" takes place. In both city cores, most of these areas can be found at the outer edge of the core. In some cases, this growth mode indicates an ageing population, which leads to decreasing household sizes. In others, it is an expression of new spacious but pricey housing offers.

(5) No growth: Neither population nor housing units are on the increase in these neighbourhoods. 13 districts in Stuttgart are in this mode compared to only one neighbourhood in Portland. Even though these areas are spatially close to hotspots of growth, they seem to lack development potential and/or demand. In case of Stuttgart's Europaviertel, an increase in population and housing is expected in the near future due to large urban transformation projects in preparation. Already today, one new inner city residential high-rise building is under construction in the Stuttgart 21 redevelopment area, an exclusive 18-storey building called Cloud No.7 that contains apartments on top of a hotel.

This small-scale analysis of population and housing growth confirmed the findings presented in section 2 indicating divergent trends of housing production in U.S. and German metro regions. We provided evidence for population-led growth patterns in the Stuttgart core area and a rather construction-led growth mode in the Portland core area. While the Stuttgart core area also shows large areas without any growth, this is not the case in Portland. Yet, fast growth is mainly concentrated in the central city of Portland and more distributed across the core in Stuttgart.

\subsection{Built expressions of reurbanisation in comparison}

It has been shown that reurbanisation can be, but is not necessarily, a result of comprehensive building activity. The relevance of housing for the central cities of Portland and Stuttgart is rooted in different traditions. In Germany, urban housing has a long tradition and makes for a substantial part of the land uses present in central cities. In built-up areas, population growth happens at rather modest rates 


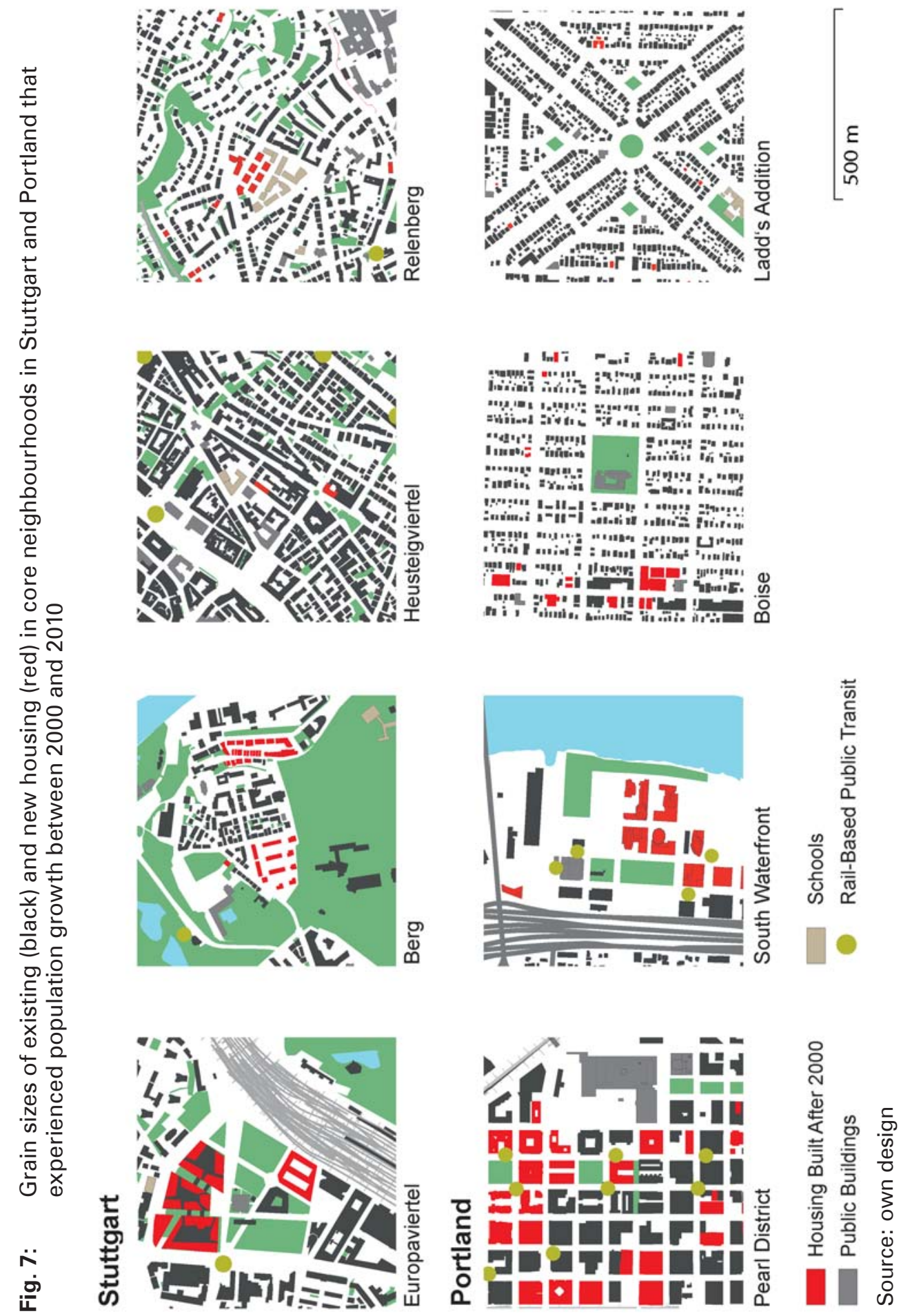


and is merely organised within the existing housing stock and at a small scale. The attractiveness of central living is also a product of ongoing, widely distributed regeneration efforts in built-up neighbourhoods. In the US, the concept of creating "mixed use zones" is a relatively new effort to reconcile the traditional separation of land uses that is much stricter than in Germany (Hirt 2013: 220, 226). In areas that experience substantial urban transformation, as in the Pearl District of the Portland case study, reurbanisation eventually means a residentialisation of areas previously not known or designated as urban living destinations. It is the result of substantial public investment into a spatially confined downtown area, in order to improve walkability and access to public transit. Here, it leads to strong densification in and change of character of these areas, whereas in urban mixed-use neighbourhoods that were dominated by housing before, only weak densification, little change of character or change in the social composition of residents takes place.

Also cultural differences become apparent when comparing the two cities: While there is a wide acceptance among families in Germany and especially in Stuttgart to raise their children in apartments in multi-family buildings, the concept of expensive, inner city high-rise living is still very new in Stuttgart and it is not yet clear who actually buys these apartments. While the standard housing situation for families in the US and in Portland is still the single-family home, residential high-rises are moving to the front in the centre of Portland since the 1990s, however, more accepted by smaller households than by families - an observation that confirms our interpretation of a "childless reurbanisation" in US cities as noted in section 2 (see also Greenblatt 2015 and Modarres/Kotkin 2013).

For both cities, it can be expected that the process of reurbanisation may continue at least for the next 10 to 15 years, as, in varying degree, local development potential is already being tapped today. Yet, this process is also limited by local availability of land and market dynamics. During the process of reurbanisation, a predominance of expensive residential development and neglect of affordable housing provision became apparent in both cities and was publicly criticised. Yet, substantial counteraction by means of planning and urban policy is generally confined, at least in inner city locations and under the market pressure currently witnessed.

\section{Conclusions and outlook}

To sum up, our analysis at the regional level shows that a residential "rediscovery of the city" can be posited for all eight analysed regions, although this began much earlier in the United States than in Germany. In addition, the processes in both countries became more dynamic over time: In the US, the positive trend of the 1990s accelerated during the 2000s, in Germany, a shift from strong suburbanisation during the 1990 s to concentration occurred in the 2000s. However, reurbanisation in both countries is taking place under strongly contrasting demographic development contexts. In Germany, the population growth which took place in regional cores and parts of the suburban surrounding was embedded in a national trend of population 
decline. In contrast, the growth of urban cores in the American regions under consideration was part of a process of dynamic population growth in the regions and the entire country. Demographic growth of the urban cores was superimposed by far stronger suburban growth.

The geography of reurbanisation also reveals differences. In the American regions, reurbanisation appeared as a location-selective process according to which relatively few census tracts displayed very high relative growth rates (see for example Dong/Zhu 2015 for Portland), which hints at a resettlement of vacant areas or areas that had previously not been used for residential purposes ("residentialisation"). Comprehensive building activity was the prerequisite for the onset of a more intense population increase. In Germany, these developments are spatially more diffuse; growth is more evenly distributed across the region's built-up central areas and the growth rates are comparatively low. It is therefore evident that reurbanisation processes in both countries differ in their degree of location selectivity.

The empirical findings illustrate that reurbanisation must be assessed as a strongly context-dependent development with distinctly varying socio-spatial characteristics and built manifestations of urban forms. The partially enormous growth rates in core areas may be seen as evidence for universal economic and social changes that have led to an increase in the significance of dense residential areas with a high degree of centrality and above-average accessibility. At the same time, locally and regionally specific contextual conditions lead to a broad variety of sociospatial changes and structural developments. Here, the mechanisms of the land and real estate markets as well as urban and regional planning appear especially relevant. In other words, the space and image producing local modes of reurbanisation demonstrate a large variety so that "reurbanisation" should be understood as an umbrella concept encompassing a huge range of potential spatial outcomes and context-specific causal mechanisms.

This finding has been further confirmed by our two case studies. We observed convergent patterns of development in general and comparable policy schemes in favour of a central city densification. However, the spatial manifestation of reurbanisation processes in terms of distributional patterns of growth and urban form differ tremendously, partly as a result of path-dependent urban structures.

In both cities, we found a "planned reurbanisation" insofar as the revaluation of central city locations is clearly the result of comprehensive public investment and policy action started around four decades ago that centred on the provision of urban infrastructure and urban amenities. Both case study municipalities succeeded in attracting new residents to their central cities and stimulating private investment there, even during and after the financial crisis. But since then, during the last couple of years, market dynamics have accelerated so much that, today, the persisting demand for centrally located housing drives up real estate prices and rents. The provision of affordable housing is a major struggle for both cities and they only recently started to tackle the social and regional dimensions of this challenge (see Davidson/Lees 2010 and Atkinson 2004 for a general debate on the relationship of reurbanisation and gentrification). Even though both cities had, beforehand, installed instruments and mechanisms to secure affordable housing for households 
with average and below average income, they do not succeed in providing enough of it. In Portland, the negative consequences of the downtown rebound such as gentrification, displacement and racial discrimination moved to the front of public debate (Coalition for a Livable Future 2007; Bates 2013; Goodling et al. 2015). In Stuttgart, the overall shortage of housing is in the centre of current political debate (Strauß 2016), a development that is connected to a decade-long neglect of provision of social housing and has recently been superimposed by the arrival of a wave of refugees from the Near and Middle East.

Comparing reurbanisation processes in the two case study cities has shown that neighbourhoods may contribute in very different modes and degrees to central city population growth. Housing production is an important factor, but it varies significantly in quantity and quality due to different historic and structural backgrounds. Whereas in the city of Stuttgart inner city housing has a long tradition and sites for new housing construction are very scarce, in Portland, like in other US-American cities, extensive derelict land gave way to major schemes of urban regeneration with high-density housing.

While our main intention was not to make forecasts on future trends of population change in US and German metro areas, we nevertheless see some evidence for a certain revival of suburbanisation. In recent years, the core cities' housing markets have increasingly priced out low and middle-income households. "The urban revival has been so thoroughgoing that it has even engendered a new crisis of success, whose symptoms are runaway gentrification, soaring housing prices and a widening income gap between newcomers and longtime residents" (Florida 2017). In both countries, declining population growth rates of the core cities and a rising amount of city-to-suburb migration have been recently observed (Maciag 2017; Busch 2016). Although we do not think that reurbanisation might manifest itself as a short-term anomaly in the light of a longer-term transformation towards greater decentralisation, it becomes clear that the residential densification of the urban cores is a finite process. The cities' ability to further grow in the future will depend on the amount of land resources and infill potential, the implementation of policies for a more socially inclusive housing production and - last but not least - on a consensus among policy makers, investors, stakeholders and citizens on the aims and forms of urban development in general and growth in particular.

Our case studies on reurbanisation show some specific limitations of comparative international urban research. Apart from the familiar methodological problems with generalising the results of case studies, it should be considered that Portland is often seen as an "exceptional" case even within the US (variables such as inner city job and population growth rates; smart growth management and sustainability policies). It therefore does not represent "average" trends in US metropoles. The same holds true for the city of Stuttgart, as it belongs to the few German urban regions with a polycentric structure that were not hit by economic decline and structural change and still boasts of a prospering regional economy. Nevertheless, we believe that a comparative approach is especially useful in its qualitiative aspects. Our housing market analysis has shown that the "built expression" of reurbanisa- 
tion covers a wide range of possible building types, intervention depths and project sizes, design styles - and even the absence of construction measures.

In closing, we believe that more comparative in-depth and context sensitive research on the local drivers and outcomes of reurbanisation is needed. Our knowledge on the causal factors of growth in some cities/neighbourhoods and stagnation or even decline in others is still limited. This also hampers future scenarios and forecasts of the persistence of inner-city densification. Moreover, future research efforts should aim at better understanding the social implications of regional and local development policies (such as "compact cities", "urban sustainability" or "smart growth"). This could pave the way towards a more inclusive mode of (re-)urbanisation in cities of the Global north.

\section{References}

Abbott, Carl 2004: Centers and edges. Reshaping downtown Portland. In: Ozawa, Connie $P$. (Ed.): The Portland edge. Challenges and successes in growing communities. Washington: Island Press: 164-183.

Atkinson, Rowland 2004: The evidence on the impact of gentrification: new lessons for the urban renaissance? In: European Journal of Housing Policy 4: 107-131 [doi: 10.1080/1461671042000215479].

Bates, Lisa K. 2013: Gentrification and Displacement Study: implementing an equitable inclusive development strategy in the context of gentrification. Commissioned by City of Portland Bureau of Planning and Sustainability 2013.

Birch, Eugenie L. 2005: Who lives downtown. The Brookings Institution. Living Cities Census Series. Washington: Brookings.

Bourne, Larry S. 1992: Population turnaround in the Canadian inner city: contextual factors and social consequences. In: Canadian Journal of Urban Research 1: 66-89.

Bourne, Larry S. 2008: On schools of thought, comparative research, and inclusiveness: A commentary. In: Urban Geography 29: 177-186 [doi: 10.2747/0272-3638.29.2.177].

Brachat-Schwarz, Werner 2008: Reurbanisierung - Gibt es eine „Renaissance der Städte“ in Baden-Württemberg? In: Statistisches Monatsheft Baden-Württemberg 11/2008: 5-13.

Brake, Klaus 2011: "Reurbanisierung" - Globalisierung und neuartige Inwertsetzung städtischer Strukturen „europäischen“ Typs. In: Frey, Oliver; Koch, Florian (Eds.): Die Zukunft der Europäischen Stadt. Stadtpolitik, Stadtplanung und Stadtgesellschaft im Wandel. Wiesbaden: Springer VS: 299-323 [doi: 10.1007/978-3-531-92653-7_18].

Brake, Klaus; Herfert, Günther (Eds.) 2012: Reurbanisierung. Materialität und Diskurs in Deutschland. Wiesbaden: Springer VS.

Brombach, Karoline; Fricke, Axel; Jessen, Johann 2014: Kommunale Strategien im Vergleich. Urbanes Wohnen in Stuttgart, Mannheim und Freiburg. Hannover: ARL: 118170 [http://nbn-resolving.de/urn:nbn:de:0156-3977079].

Brookings Institution 2010: State of Metropolitan America. On the front lines of demographic transformation. Washington DC.

Busch, Roland 2016: Inländische Wanderungen in Deutschland - wer gewinnt und wer verliert? Zeitschrift für Immobilienökonomie 2,2: 81-101 [doi: 10.1365/s41056-0160012-3]. 
Buzar, Stefan et al. 2007: Splintering urban populations. Emergent landscapes of reurbanization in four European cities. In: Urban Studies 44,4: 651-677 [doi: 10.1080/00420980601185544].

Cheshire, Paul 1995: A new phase of urban development in Western Europe. The Evidence for the 1980s. In: Urban Studies 32,7: 1045-1063 [doi: 10.1080/00420989550012564].

Clark, Terry N. et al. 2002: Amenities drive urban growth. In: Journal of Urban Affairs 24,5: 493-515 [doi: 10.1111/1467-9906.00134].

Coalition for a Livable Future 2007: Regional Equity Atlas. Portland 2007.

Danielsen, Karen A; Lang, Robert, E. 2010: Live work play. New perspectives on the downtown rebound. In: DisP - The Planning Review 46,180: 91-105 [doi: 10.1080/0251 3625.2010.10557066].

Davidson, Mark; Lees, Loretta 2010: New-build gentrification: Its histories, trajectories, and critical geographies. Population, Space and Place 16,5: 395-411 [doi: 10.1002/ psp.584].

DiGaetano, Alain; Strom, Elizabeth 2003: Comparative Urban Governance. An Integrated Approach. In: Urban Affairs Review 38,3: 356-395 [doi: 10.1177/1078087402238806].

Dong, Hongwei; Zhu Pengyu 2015: Smart growth in two contrastive metropolitan areas: A comparison between Portland and Los Angeles. In: Urban Studies 52,4: 775-792 [doi: 10.1177/0042098014528396].

Engler, Philip 2013: Reurbanisierung als wissenschaftliches Konzept - Plädoyer für eine Konzeptualisierung als Bedeutungszunahme des Städtischen. In: DisP - The Planning Review 49,2: 14-27 [doi: 10.1080/02513625.2013.826534].

Estiri Hossein; Krause, Andy; Heris, Mehdi P. 2015: 'Phasic' metropolitan settlers: a phase-based model for the distribution of households in US metropolitan regions. In: Urban Geography 36,5: 777-794 [doi: 10.1080/02723638.2015.1005921].

Fishman, Robert 2005: Longer View: The Fifth Migration. In: Journal of the American Planning Association 71,4: 357-366 [doi: 10.1080/01944360508976706].

Florida, Richard 2017: The urban revival is over. New York Times, Sept 1., 2017 [https://www.nytimes.com/2017/09/01/opinion/cities-suburbs-housing-crime.html, 05.10.2017].

Florida, Richard 2002: The rise of the creative class ... and how it's transforming work, leisure, community, \& everyday life. New York: Basic Books.

Frank, Susanne 2016: Inner-city suburbanization - no contradiction in terms. Middleclass family enclaves are spreading in the cities. In: Raumforschung und Raumordnung: 1-10 [doi: 10.1007/s13147-016-0444-1].

Frey, William, H. 1993: The new urban revival in the United States. In: Urban Studies 30,4-5: 741-774 [doi: 10.1080/00420989320081901].

Geppert, Kurt; Gornig, Martin 2010: Mehr Jobs, mehr Menschen: Die Anziehungskraft der großen Städte wächst. In: DIW Wochenbericht 19: 2-10.

Getimis, Panagiotis 2012: Comparing Spatial Planning Systems and Planning Cultures in Europe. The Need for a Multi-scalar Approach. In: Planning Practice and Research 27: 25-40 [doi: 10.1080/02697459.2012.659520].

Glaeser, Edward L.; Gottlieb, Joshua D. 2006: Urban resurgence and the consumer city. In: Urban Studies 43,8: 1275-1299 [doi: 10.1080/00420980600775683].

Glasze, Georg; Graze, Philip 2007: Raus aus Suburbia, rein in die Stadt. Studie zur zukünftigen Wohnmobilität von Suburbaniten der Generation 50+. In: Raumforschung und Raumordnung 5: 467-473. 
Glatter, Jan; Siedhoff, Mathias 2008: Reurbanization: Inflationary use of an insufficiently defined term? Comments on the definition of a key concept of urban geography, with selected findings for the city of Dresden. In: Die Erde 139: 289-308.

Goodling, Erin; Green, Jamaal; McClintock, Nathan 2015: Uneven Development of the Sustainable City: Shifting Capital in Portland, Oregon. In: Urban Geography 36,4: 504527 [doi: 10.1080/02723638.2015.1010791].

Gordon, Peter; Cox, Wende/l 2012: Cities in Western Europe and the United States: do policy differences matter? In: The Annals of Regional Science 48,2: 565-594 [doi: 10.1007/s00168-011-0495-8].

Greenblatt, Alan 2015: Do cities need kids? Governing Magazine, February 2015.

Growe, Anna; Münter, Angelika 2010: Die Renaissance der großen Städte. In: Geographische Rundschau 11: 54-59.

Harlander, Tilman; Jessen, Johann 2001: Stuttgart - polyzentrale Stadtregion im Strukturwandel. In: Brake, Klaus; Dangschat, Jens S.; Herfert, Günther (Eds.): Suburbanisierung in Deutschland. Aktuelle Tendenzen. Opladen: Leske + Budrich: 187-199.

Haußmann, Michae/ 2007: Trend zurück in die Innenstädte. In: Statistik- und Informationsmanagement Stuttgart 9/2007: 255.

Heinig, Stefan; Herfert, Günter 2012: Leipzig - intraregionale und innerstädtische Reurbanisierungspfade. In: Brake, Klaus; Herfert, Günther (Eds.): Reurbanisierung. Materialität und Diskurs in Deutschland. Wiesbaden: Springer VS: 323-342 [doi: 10.1007/9783-531-94211-7_18].

Helbrecht, I/se 1996: Die Wiederkehr der Innenstädte. Zur Rolle von Kultur, Kapital und Konsum im Prozeß in der Gentrification. In: Geographische Zeitschrift 84: 1-15.

Henger, Ralph; Schier, Michael; Voigtländer, Michael 2015: Baubedarfe - Stadt und Land fallen auseinander. In: Wirtschaftsdienst 95,11: 796-798 [doi: 10.1007/s10273015-1904-x].

Hirt, Sonia 2013: Form Follows Function? How America Zones: In: Planning, Practice and Research 28,2: 204-230 [doi: 10.1080/02697459.2012.692982].

Holm, Andrej 2012: Paradoxien und Begleiterscheinungen der Reurbanisierung. In: Brake, Klaus; Herfert, Günter (Eds.): Reurbanisierung. Materialität und Diskurs in Deutschland. Wiesbaden: Springer VS: 239-256 [doi: 10.1007/978-3-531-94211-7_14].

Jessen, Johann; Mayer, Heike 2010: Reurbanisierung und Flächenrecycling. Portland und Stuttgart. In: Informationen zur Raumentwicklung 1/2010: 27-41.

Jessen, Johann; Siedentop, Stefan; Zakrzewski, Philipp 2012: Rezentralisierung der Stadtentwicklung. Kleinräumige Analyse des Wanderungsgeschehens in deutschen Großstädten. In: Brake, Klaus; Herfert, Günter (Eds.): Reurbanisierung. Materialität und Diskurs in Deutschland. Wiesbaden: Springer VS: 198-215 [doi: 10.1007/978-3531-94211-7_12].

Juday, Luke J. 2015: The changing shape of American cities. Charlottesville: Demographics Research Group. Weldon Cooper Center for Public Service: University of Virginia.

Kantor, Paul; Savitch, Hank V. 2005: How to study comparative urban development politics: A research note. In: International Journal of Urban and Regional Research 29,1: 135-151 [doi: 10.1111/j.1468-2427.2005.00575.x].

Koll-Schretzenmayr, Martina; Kramp, Simon 2010: Reurbanisierung und bauliche Dynamik. Neubautätigkeiten und ihre räumlichen und sozioökonomischen Auswirkungen in der Stadt Zürich. In: disP - The Planning Review 46,180: 60-80 [doi: 10.1080/02513 625.2010.10557064]. 
Krätke, Stefan 2014: Cities in Contemporary Capitalism. In: International Journal of Urban and Regional Research 38,5: 1660-1677 [doi: 10.1111/1468-2427.12165].

Lambert, Christine; Boddy, Martin 2010: City center housing in the UK. Prospects and policy changes in a changing housing market. In: disP - The Planning Review 46,180: 47-59 [doi: 10.1080/02513625.2010.10557063].

Landis, John 2009: The changing shape of metropolitan America. In: The Annals of the American Academy of Political and Social Science 626,1: 154-191 [doi: 10.1177/0002716209344837].

Le Galès, Patrick; Zagrodzki, Mathieu 2006: Cities are back in town: The US/Europe comparison. Centre d'Etudes Européennes de Sciences Po. Paris.

Lever, William F. 1993: Reurbanization - The policy implications. In: Urban Studies 30,2: 267-284 [doi: 10.1080/00420989320080281].

Lewis, Rebecca; Knaap, Gerrit; Schindewolf, Jamie 2013: The spatial structure of cities in the United States [http://smartgrowth.umd.edu/assets/documents/research/lewisknaapschindewolf_spatialstructure_2013.pdf, 19.05.2014].

Maciag, Mike 2017: Population Growth Shifts to Suburban America. In: Governing Magazine, June 2017 [http://www.governing.com/topics/urban/gov-suburban-populationgrowth.html, 05.10.2017].

Meng, Rüdiger; Schmitz-Veltin, Ansgar; West, Christina 2008: Wohnen in der Stadt? Wohnwünsche intraurban wachsender Haushalte und potenzielle Reurbanisierier am Beispiel der Stadt Mannheim. In: Maretzke, Steffen (Ed.): Städte im demografischen Wandel: Wesentliche Strukturen und Trends des demografischen Wandels in den Städten Deutschlands. Materialien zur Bevölkerungswissenschaft 125. Wiesbaden: $\mathrm{BiB}$.

Modarres, Ali; Kotkin, Joe/ 2013: The childless city. It's hip, it's entertaining - but where are the families? In: Magazine City Journal, Summer 2013.

Müller, Bernhard; Siedentop, Stefan 2004: Wachstum und Schrumpfung in Deutschland - Trends, Perspektiven und Herausforderungen für die räumliche Planung und Entwicklung. In: Deutsche Zeitschrift für Kommunalwissenschaften 43,1: 14-32.

Moos, Markus 2015: From gentrification to youthification? The increasing importance of young age in delineating high-density living. In: Urban Studies 53,14: 2903-2920 [doi: 10.1177/0042098015603292].

Mulherin, Stephen; Howell, Gareth 2012: Changes in downtown Los Angeles and the Fifth Migration 1990-2010. In: Heralds Journal of Geography and Regional Planning 1,2: 19-35.

Nivola, Pietro 1999: How Policies Shape Cities in Europe and America. Washington: Brookings Institution.

Nowlan, David M.; Stewart, Greg 1991: Downtown population growth and commuting trips. Recent experience in Toronto. In: Journal of the American Planning Association 57,2: 165-182 [doi: 10.1080/01944369108975485].

Ogden, Philip E.; Hall, Ray 2004: The second demographic transition, new household forms and the urban Population of France during the 1990s. In: Transactions of the Institute of British Geographers 29,1: 88-105 [doi: 10.1111/j.0020-2754.2004.00116.x].

Pierre, Jon 2005: Comparative Urban Governance: Uncovering Complex Causalities. In: Urban Affairs Review 40,4: 446-462 [doi: 10.1177/1078087404273442].

Rérat, Patrick 2012: The new demographic growth of cities: The case of reurbanization in Switzerland. In: Urban Studies 49,5: 1107-1125 [doi: 10.1177/0042098011408935]. 
Schmitz-Veltin, Ansgar 2015: Reurbanisierung im Kontext einer neuen Unübersichtlichkeit regionaler Entwicklungsmuster. Das Beispiel der Stadtregion Stuttgart. Arbeitsberichte der ARL 14. Hannover: ARL: 77-95 [URN: urn:nbn:de:0156-3977058].

Schrock, Greg; Jurjevich, Jason 2012: Is Portland really the place where young people go to retire. Analyzing labor market outcomes for Portland's young and college-educated [http://mkn.research.pdx.edu/wpcontent/uploads/2012/09/SchrockJurjevich_ YCELaborMarket_Full1.pdf, 20.05.2014].

Sellers, Jefferey M. 2005: Re-Placing the Nation. An Agenda for Comparative Urban Politics. In: Urban Affairs Review 40,4: 419-445 [doi: 10.1177/1078087404272673].

Siebel, Walter 2008: Wohnen in der Innenstadt. In: Deutsche Zeitschrift für Kommunalwissenschaften 47: 37-46.

Siebel, Walter; Häußermann, Hartmut 1987: Neue Urbanität. Frankfurt: Suhrkamp.

Siedentop, Stefan; Stroms, Peter; Zakrzewski, Philipp 2017: A Childless Urban Renaissance? Age selective patterns of population change in North American and German Metropolitan Areas. In: Regional Studies, Regional Science (forthcoming).

Sohmer, Rebecca R.; Lang, Robert E. 2001: Downtown rebound [http://www.downtownhouston.org/site_media/uploads/attachments/2010-04-07/3DDowntown_Rebound_-_Fannie_Mae_The_Brookings_Institution_2001.pdf, 20.05.2014].

Stead, Dominic; Nadin, Vincent 2009: Planning cultures between models of society and planning systems. In: Knieling, Jörg; Othengrafen, Frank (Eds.): Planning Cultures in Europe. London: Ashgate: 284-300.

Storper, Michael; Scott, Aallan J. 2009: Rethinking human capital, creativity and urban growth. In: Journal of Economic Geography 9: 147-167.

Strauß, Wolf-Christian 2016: Fallstudie Umgang mit „Gentrifizierung“ in Stuttgart. Gutachten des Deutschen Instituts für Urbanistik. Berlin.

Turok, Ivan; Mykhnenko, Vlad 2008: Resurgent European cities. In: Urban Research \& Practice 1,1: 54-77 [doi: 10.1080/17535060701795363].

Urban Task Force 1999: Towards an Urban Renaissance. London: Spon.

Van Criekingen, Mathieu 2009: 'Gentrifying the reurbanization debate', not vice versa: The uneven sociospatial implications of changing transitions to adulthood in Brussels. In: Population, Space and Place 16,5: 381-394 [doi: 10.1002/psp.582].

Van den Berg, Leo et al. 1982: Urban Europe: A study of growth and decline. Oxford: Pergamon Press. 
Dr. Karoline Brombach ( $\bowtie)$. Prof. Dr. Johann Jessen. Universität Stuttgart, StädtebauInstitut. Stuttgart, Germany.

E-mail: kb@brombach.me, johann.jessen@si.uni-stuttgart.de

URL: https://www.researchgate.net/project/Reurbanisierung-in-Deutschlandund-den-USA-Eine-vergleichende-Untersuchung-der-Ursachen-und-raeumlichenAuspraegungen-von-demographischen-Reurbanisierungsprozessen-in-denStadtregionen-Portland-USA-un

URL: https://www.uni-stuttgart.de/si/orl/ORL_forschung/projekte/forschung_laufend.htm

Prof. Dr. Stefan Siedentop. Research Institute for Regional and Urban Development (ILS). Dortmund, Germany.

E-mail: stefan.siedentop@ils-forschung.de

URL: https://www.ils-forschung.de/index.php?lang=de\&s=siedentop

Philipp Zakrzewski. Ministerium für Landesentwicklung und Verkehr des Landes Sachsen-Anhalt. Magdeburg, Germany.

E-mail: philipp.zakrzewski@mlv.sachsen-anhalt.de

URL: https://mlv.sachsen-anhalt.de/themen/raumordnung-und-landesentwicklung/ interreg-projekte/greenersites/ 


\section{Comparative Population Studies}

wWW.comparativepopulationstudies.de

ISSN: 1869-8980 (Print) - 1869-8999 (Internet)

\section{Published by}

Prof. Dr. Norbert F. Schneider

Federal Institute for Population Research D-65180 Wiesbaden / Germany

\section{(cc) BY-SA}

2017

\section{Managing Editor}

Frank Swiaczny

\section{Assistant Managing Editor}

Katrin Schiefer

\section{Copy Editor}

(Selected Articles in German)

Dr. Evelyn Grünheid

\section{Layout}

Beatriz Feiler-Fuchs

E-mail: cpos@bib.bund.de

\section{Scientific Advisory Board}

Paul Gans (Mannheim)

Karsten Hank (Cologne)

Johannes Huinink (Bremen)

Michaela Kreyenfeld (Rostock)

Marc Luy (Vienna)

Notburga Ott (Bochum)

Peter Preisendörfer (Mainz)

Nikola Sander (Groningen)

Zsolt Spéder (Budapest)

\section{Board of Reviewers}

Martin Abraham (Erlangen)

Laura Bernardi (Lausanne)

Hansjörg Bucher (Bonn)

Claudia Diehl (Konstanz)

Andreas Diekmann (Zurich)

Gabriele Doblhammer-Reiter (Rostock)

Jürgen Dorbritz (Wiesbaden)

Anette Eva Fasang (Berlin)

E.-Jürgen Flöthmann (Bielefeld)

Alexia Fürnkranz-Prskawetz (Vienna)

Beat Fux (Salzburg)

Joshua Goldstein (Berkeley)

Sonja Haug (Regensburg)

Hill Kulu (Liverpool)

Aart C. Liefbroer (The Hague)

Kurt Lüscher (Konstanz)

Emma Lundholm (Umeå)

Nadja Milewski (Rostock)

Dimiter Philipov (Vienna)

Roland Rau (Rostock)

Tomáš Sobotka (Vienna)

Jeroen Spijker (Barcelona)

Olivier Thévenon (Paris)

Helga de Valk (Brussels)

Heike Trappe (Rostock)

Michael Wagner (Cologne) 